\title{
Carbon cycle uncertainty in the Alaskan Arctic
}

J. B. Fisher ${ }^{1}$, M. Sikka ${ }^{1}$, W. C. Oechel ${ }^{2}$, D. N. Huntzinger ${ }^{3}$, J. R. Melton ${ }^{4}$, C. D. Koven ${ }^{5}$, A. Ahlström ${ }^{6}$, M. A. Arain ${ }^{7}$,

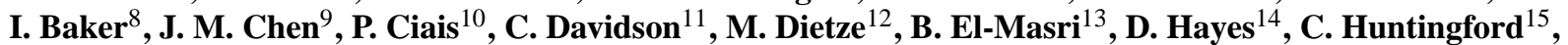

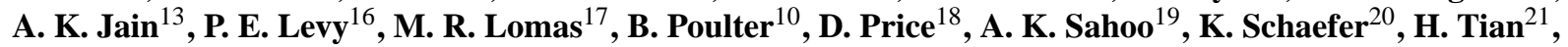
E. Tomelleri ${ }^{22}$, H. Verbeeck ${ }^{23}$, N. Viovy ${ }^{10}$, R. Wania ${ }^{24}$, N. Zeng ${ }^{25}$, and C. E. Miller ${ }^{1}$

${ }^{1}$ Jet Propulsion Laboratory, California Institute of Technology, 4800 Oak Grove Drive, Pasadena, CA, 91109, USA

${ }^{2}$ Global Change Research Group, Department of Biology, San Diego State University, San Diego, CA, 92182, USA and the Department of Environment, Earth, and Ecosystems, The Open University, Milton Keynes, UK

${ }^{3}$ School of Earth Sciences \& Environmental Sustainability, Northern Arizona University, PO Box 5694, Flagstaff, AZ, 86011, USA

${ }^{4}$ Canadian Centre for Climate Modelling and Analysis, Environment Canada, Victoria, BC, V8W 2Y2, Canada

${ }^{5}$ Earth Sciences Division, Lawrence Berkeley National Laboratory, Berkeley, CA, 94708, USA

${ }^{6}$ Department of Physical Geography and Ecosystem Science, Lund University, Sölvegatan 12, 223 62, Lund, Sweden

${ }^{7}$ School of Geography Earth Sciences and McMaster Centre for Climate Change, McMaster University,

Hamilton, ON, Canada

${ }^{8}$ Atmospheric Science Department, Colorado State University, Fort Collins, CO, 80523-1371, USA

${ }^{9}$ Department of Geography, University of Toronto, 100 St. George Street, Toronto, Ontario, M5S 3G3, Canada

${ }^{10}$ Laboratoire des Sciences du Climat et l'Environnement, Orme des Merisiers, bat. 701 - Point courier 129,

91191 Gif Sur Yvette, France

${ }^{11}$ Program in Ecology, Evolution, and Conservation Biology, University of Illinois at Urbana-Champaign, 505 S. Goodwin Ave, Urbana, IL, 61801, USA

${ }^{12}$ Department of Earth and the Environment, Boston University, 675 Commonwealth Ave, Boston, MA, 02215, USA

${ }^{13}$ Department of Atmospheric Sciences, University of Illinois, Urbana, IL, 61801, USA

${ }^{14}$ Climate Change Science Institute and Environmental Sciences Division, Oak Ridge National Laboratory, Oak Ridge, TN, 37831-6301, USA

${ }^{15}$ Centre for Ecology and Hydrology, Benson Lane, Wallingford, OX10 8BB, UK

${ }^{16}$ Centre for Ecology and Hydrology, Penicuik, Midlothian, EH26 0QB, UK

${ }^{17}$ Centre for Terrestrial Carbon Dynamics, University of Sheffield, Dept. of Animal \& Plant Sciences, Western Bank, Sheffield, S10 2TN, UK

${ }^{18}$ Natural Resources Canada, Northern Forestry Centre, 5320 - 122 Street Northwest, Edmonton, Alberta, T6H 3S5, Canada

${ }^{19}$ Department of Civil and Environmental Engineering, Princeton University, Princeton, New Jersey, 08544, USA

${ }^{20}$ National Snow and Ice Data Center, Cooperative Institute for Research in Environmental Sciences, University of Colorado at Boulder, Boulder, CO, 80309, USA

${ }^{21}$ School of Forestry and Wildlife Sciences, Auburn University, 602 Duncan Drive, Auburn, AL, 36849, USA

${ }^{22}$ Biogeochemical Model-Data Integration Group, Max Planck Institute for Biogeochemistry, Hans-Knöll-Str. 10, 07745, Jena, Germany

${ }^{23}$ Laboratory of Plant Ecology, Faculty of Bioscience Engineering, Ghent University, Coupure Links 653, 9000 Ghent, Belgium

${ }^{24}$ Institut des Sciences de l'Evolution (UMR5554, CNRS), Université Montpellier 2, Place Eugène Bataillon, 34090 Montpellier, France

${ }^{25}$ Department of Atmospheric and Oceanic Science, University of Maryland, 2417 Computer and Space Sciences Building, College Park, MD, 20742-2425, USA

Correspondence to: J. B. Fisher (jbfisher@jpl.nasa.gov) 
Received: 22 January 2014 - Published in Biogeosciences Discuss.: 20 February 2014

Revised: 17 June 2014 - Accepted: 22 June 2014 - Published: 14 August 2014

\begin{abstract}
Climate change is leading to a disproportionately large warming in the high northern latitudes, but the magnitude and sign of the future carbon balance of the Arctic are highly uncertain. Using 40 terrestrial biosphere models for the Alaskan Arctic from four recent model intercomparison projects - NACP (North American Carbon Program) site and regional syntheses, TRENDY (Trends in net land atmosphere carbon exchanges), and WETCHIMP (Wetland and Wetland $\mathrm{CH}_{4}$ Inter-comparison of Models Project) - we provide a baseline of terrestrial carbon cycle uncertainty, defined as the multi-model standard deviation $(\sigma)$ for each quantity that follows. Mean annual absolute uncertainty was largest for soil carbon $\left(14.0 \pm 9.2 \mathrm{~kg} \mathrm{C} \mathrm{m}^{-2}\right)$, then gross primary production (GPP) $\left(0.22 \pm 0.50 \mathrm{~kg} \mathrm{C} \mathrm{m}^{-2} \mathrm{yr}^{-1}\right)$, ecosystem respiration (Re) $\left(0.23 \pm 0.38 \mathrm{~kg} \mathrm{C} \mathrm{m}^{-2} \mathrm{yr}^{-1}\right)$, net primary production (NPP) $\left(0.14 \pm 0.33 \mathrm{~kg} \mathrm{C} \mathrm{m}^{-2} \mathrm{yr}^{-1}\right)$, autotrophic respiration (Ra) $\left(0.09 \pm 0.20 \mathrm{~kg} \mathrm{C} \mathrm{m}^{-2} \mathrm{yr}^{-1}\right)$, heterotrophic respiration (Rh) $\left(0.14 \pm 0.20 \mathrm{~kg} \mathrm{C} \mathrm{m}^{-2} \mathrm{yr}^{-1}\right)$, net ecosystem exchange (NEE) $\left(-0.01 \pm 0.19 \mathrm{~kg} \mathrm{C} \mathrm{m}^{-2} \mathrm{yr}^{-1}\right)$, and $\mathrm{CH}_{4}$ flux $\left(2.52 \pm 4.02 \mathrm{~g} \mathrm{CH}_{4} \mathrm{~m}^{-2} \mathrm{yr}^{-1}\right)$. There were no consistent spatial patterns in the larger Alaskan Arctic and boreal regional carbon stocks and fluxes, with some models showing NEE for Alaska as a strong carbon sink, others as a strong carbon source, while still others as carbon neutral. Finally, Ameriflux data are used at two sites in the Alaskan Arctic to evaluate the regional patterns; observed seasonal NEE was captured within multi-model uncertainty. This assessment of carbon cycle uncertainties may be used as a baseline for the improvement of experimental and modeling activities, as well as a reference for future trajectories in carbon cycling with climate change in the Alaskan Arctic and larger boreal region.
\end{abstract}

\section{Introduction}

Changes in climate have led to a relatively large warming in the high northern latitudes, that is, the Arctic, due to a temperature-albedo feedback from the loss of snow and sea ice, as well as the breakdown of polar near-surface temperature inversions (i.e., more water vapor, leading to greater greenhouse gas effect; also, changes in cloud cover) (Cess et al., 1991; Chapin et al., 2005; Chapman and Walsh, 1993, 2007; IPCC, 2007; McGuire et al., 2006; Overpeck et al., 1997; Serreze et al., 2000; Walsh et al., 2002). Throughout the Holocene, Arctic ecosystems have absorbed more $\mathrm{CO}_{2}$ from the atmosphere through photosynthesis than have emitted back to the atmosphere through respiration (Kuhry et al., 2009; Marion and Oechel, 1993; Oechel et al., 1993; Ping et al., 2008; Tarnocai, 2006). The pervasive cold and wet conditions in the Arctic have limited the decay of soil organic carbon, resulting in the accumulation of carbon on the order of $35-70 \mathrm{~kg} \mathrm{C} \mathrm{m}^{-2}$ total ( $\sim 25 \%$ of the global soil organic carbon pool; Mishra and Riley, 2012; Ping et al., 2008; Tarnocai et al., 2009) stored above and beneath the permafrost and in peatlands over centuries to millennia.

Warming, however, is thawing permafrost and changing the soil water balance and water table, resulting in the release of previously stored soil carbon to the atmosphere, thereby exacerbating the atmospheric $\mathrm{CO}_{2}$ impact on the climate (Belshe et al., 2013, 2012; Burke et al., 2012; Christensen et al., 2004; Hayes et al., 2011; Koven et al., 2011; McGuire et al., 2009; Natali et al., 2012, 2014; Oechel et al., 1993, 2000; Oechel and Vourlitis, 1994; Schaefer et al., 2011; Schuur and Abbott, 2011; Schuur et al., 2008, 2009, 2013; Zimov et al., 2006). Alternatively, warming accelerates soil decomposition, which may release nutrients into the nutrient-limited ecosystems, and, combined with more favorable growing conditions and additional growing days, drive the Arctic towards a carbon sink regime (Mack et al., 2004; Qian et al., 2010; Sistla et al., 2013). While pointbased measurements in the Alaskan Arctic indicate that it is currently a net $\mathrm{CO}_{2}$ source to the atmosphere (Oechel et al., 1993, 2000, 2014; Oechel and Vourlitis, 1994), given the lack of continuous, large-scale observations of the Arctic net ecosystem exchange (NEE) of $\mathrm{CO}_{2}$ it is still impossible to determine with certainty whether or not the Arctic is a net carbon sink or source, let alone the future Arctic $\mathrm{CO}_{2}$ flux magnitude or even sign of flux (Hinzman et al., 2005; McGuire et al., 2009, 2012).

A number of new field campaigns aim to address these uncertainties: the Carbon in Arctic Reservoirs Vulnerability Experiment (CARVE; NASA) (Miller et al., 2010), the Arctic Boreal Vulnerability Experiment (ABoVE) (Goetz et al., 2011), and the Next Generation Ecological Experiment (NGEE Arctic) (Wullschleger et al., 2011). All of these campaigns focus on Alaskan Arctic and boreal zones as the major region of study, aiming to reduce uncertainty in the Arctic and boreal carbon cycle. However the uncertainty has not been well quantified. McGuire et al. (2012) provided the closest solution to this problem, compiling global and regional land and atmospheric models to quantify pan-Arctic carbon budgets, and our paper builds on this groundbreaking effort with a narrowed regional and topical focus on Alaskan Arctic and boreal carbon uncertainties, sensitivities, and spatial patterns. Our analysis is specifically designed for application to these Alaskan field campaigns, which require justification for geographic sampling decisions needed across Alaska as a single domain; we provide the spatial distribution 
of uncertainties where McGuire et al. did not. We also include in situ measurements from AmeriFlux sites within the Alaskan Arctic for quantitative comparison to simulation results. Moreover, we expand the uncertainty quantification to four times as many carbon cycle variables across four times as many terrestrial biosphere models, necessary for understanding how uncertainty values are constructed in global climate change projections (Friedlingstein et al., 2006; IPCC, 2007).

This effort is made possible by recent terrestrial biosphere model intercomparison projects (MIPs) - TRENDY (Piao et al., 2013), the North American Carbon Program (NACP) regional and site syntheses (Hayes et al., 2012; Huntzinger et al., 2012; Schwalm et al., 2010), and the Wetland and Wetland $\mathrm{CH}_{4}$ Inter-comparison of Models Project (WETCHIMP) (Melton et al., 2013; Wania et al., 2013) - which have organized a multitude of international modeling teams to contribute their latest model estimates using both common forcing data (i.e., TRENDY, NACP site, WETCHIMP) as well as a mixture of different forcing data (i.e., NACP regional). These MIPs extended from global (TRENDY, WETCHIMP) to regional (NACP regional) to site level (NACP site) domains. The models included in these MIPs form the scientific community's understanding of global carbon cycle processes, with large uncertainties globally stemming from large uncertainties regionally and locally, particularly for the Arctic. The scientific community has been focused on diagnoses of individual model skill, benchmarking, and suggestions for improvements, and we defer to other papers for such analyses (Huntzinger et al., 2012; Schaefer et al., 2012; Schwalm et al., 2010).

Here, we use the between-model variability from these MIPs to define the uncertainties in the Alaskan Arctic and boreal carbon cycle. This total uncertainty integrates both structural uncertainty of land-surface physics among models as well as inherent parametric uncertainty introduced within models, and uncertainty from forcing data. Finally, to understand the absolute skill of model estimates, we evaluate the performance of the models against in situ measurements of carbon fluxes at AmeriFlux sites along the Alaskan North Slope. The objective of this analysis is to compile and quantify the predictive uncertainty in terrestrial carbon cycle dynamics applied to the Alaskan Arctic and boreal region to provide a baseline of uncertainty and spatial maps geolocating this uncertainty for current and future field campaigns in the region. The primary focus of the uncertainty calculations is on the Alaskan North Slope or "Alaskan Arctic"; however, we also provide maps of the larger Arctic and boreal region encompassing the entire state of Alaska.

\section{Methods}

\subsection{Regional level}

We used 14 NACP regional synthesis models, 9 TRENDY models, and 7 WETCHIMP models for regional carbon flux and/or stock estimates.

The 14 NACP regional synthesis models include (Table 1): BEPS (Chen et al., 1999), CanIBIS (El Maayar et al., 2002), CASA-GFED (van der Werf et al., 2004), CASA-TRANSCOM (Randerson et al., 1997), CLM-CASA (Randerson et al., 2009), CLM4-CN (Thornton et al., 2007), DLEM (Tian et al., 2010), ISAM (Jain and Yang, 2005), LPJwsl (Sitch et al., 2003), MOD17 (Zhao et al., 2005), ORCHIDEE (Krinner et al., 2005), SiB3 (Baker et al., 2008), TEM6 (Hayes et al., 2011), and VEGAS2 (Zeng et al., 2005). Model output for the NACP regional synthesis was downloaded from: ftp://nacp.ornl.gov/synthesis/2008/firenze/continental/ 1_continental_data_model_inventory.html. All NACP regional synthesis models were provided at $1^{\circ} \times 1^{\circ}$ spatial resolution.

The nine TRENDY models include: CLM4-CN (Thornton et al., 2007), HYLAND (Levy et al., 2004), LPJwsl (Sitch et al., 2003), LPJ-GUESS (Smith et al., 2001), OCN (Zaehle et al., 2010), ORCHIDEE (Krinner et al., 2005), SDGVM (Cramer et al., 2001), TRIFFID (Clark et al., 2011), and VEGAS (Zeng et al., 2005). Model output for TRENDY was downloaded from: http://www-lscedods.cea. fr/invsat/RECCAP/. Output from multiple versions of the same model were sometimes available; in these cases, we used output only from the most recent version. We primarily used the version $\mathrm{S} 2$ runs, which correspond to simultaneously meteorological forcings and atmospheric $\mathrm{CO}_{2}$ concentration variation following 20th century increases, with disturbance turned off and a constant land use mask. We also used version $\mathrm{S} 1$, which varies only $\mathrm{CO}_{2}$, to evaluate sensitivities to $\mathrm{CO}_{2}$ and climate. Model LPJ-GUESS, LPJwsl, and ORCHIDEE were provided at $0.5^{\circ} \times 0.5^{\circ}$ spatial resolution; $\mathrm{CLM} 4 \mathrm{CN}$ at $1.875^{\circ} \times 2.5^{\circ}$ spatial resolution; VEGAS at $2.5^{\circ} \times 2.5^{\circ}$ spatial resolution; and HYLAND, OCN, SDGVM, and TRIFFID at $2.5^{\circ} \times 3.75^{\circ}$ spatial resolution.

The seven WETCHIMP models include: CLM4Me (Riley et al., 2011b), DLEM (Tian et al., 2010), LPJ-Bern (Spahni et al., 2011), LPJ-WHyMe (Wania et al., 2010), LPJwsl (Sitch et al., 2003), ORCHIDEE (Krinner et al., 2005), and SDGVM (Cramer et al., 2001). Model output for WETCHIMP was downloaded from: http://arve.unil.ch/ pub/wetchimp. Output from six experiments were available (Melton et al., 2013), but we used only experiment 2, corresponding to the transient simulation from 1901 to 2009 using observed climate and $\mathrm{CO}_{2}$ values. Models DLEM, LPJBern, LPJ-WHyMe, SDGVM, and LPJwsl were provided at $0.5^{\circ} \times 0.5^{\circ}$ spatial resolution; ORCHIDEE at $1^{\circ} \times 1^{\circ}$ spatial resolution; and CLM4me at $1.9^{\circ} \times 2.5^{\circ}$ spatial resolution. 
Table 1. Models and carbon output variables.

\begin{tabular}{|c|c|c|c|c|c|c|c|c|}
\hline & NEE & GPP & $\operatorname{Re}$ & $\mathrm{Rh}$ & $\mathrm{Ra}$ & NPP & Csoil & $\mathrm{CH}_{4}$ \\
\hline \multicolumn{9}{|c|}{ NACP regional } \\
\hline BEPS & $\sqrt{ }$ & $\sqrt{ }$ & $\sqrt{ }$ & $\sqrt{ }$ & $\sqrt{ }$ & $\sqrt{ }$ & & \\
\hline Can-IBIS & $\sqrt{ }$ & $\sqrt{ }$ & $\sqrt{ }$ & $\sqrt{ }$ & $\sqrt{ }$ & $\sqrt{ }$ & $\sqrt{ }$ & \\
\hline CASA-GFED & $\sqrt{ }$ & $\sqrt{ }$ & $\sqrt{ }$ & & & & & \\
\hline CASA-TRANSCOM & $\sqrt{ }$ & & & & & & & \\
\hline CLM-CASA & $\sqrt{ }$ & $\sqrt{ }$ & $\sqrt{ }$ & $\sqrt{ }$ & $\sqrt{ }$ & $\sqrt{ }$ & $\sqrt{ }$ & \\
\hline CLM4-CN & $\sqrt{ }$ & $\sqrt{ }$ & $\sqrt{ }$ & $\sqrt{ }$ & $\sqrt{ }$ & $\sqrt{ }$ & $\sqrt{ }$ & \\
\hline DLEM & $\sqrt{ }$ & $\sqrt{ }$ & $\sqrt{ }$ & $\sqrt{ }$ & $\sqrt{ }$ & $\sqrt{ }$ & $\sqrt{ }$ & \\
\hline ISAM & $\sqrt{ }$ & & & $\sqrt{ }$ & & $\sqrt{ }$ & & \\
\hline LPJwsl & $\sqrt{ }$ & $\sqrt{ }$ & $\sqrt{ }$ & $\sqrt{ }$ & $\sqrt{ }$ & $\sqrt{ }$ & $\sqrt{ }$ & \\
\hline MOD17 & $\sqrt{ }$ & $\sqrt{ }$ & $\sqrt{ }$ & & & & & \\
\hline ORCHIDEE & $\sqrt{ }$ & $\sqrt{ }$ & $\sqrt{ }$ & $\sqrt{ }$ & $\sqrt{ }$ & $\sqrt{ }$ & & \\
\hline $\mathrm{SiB} 3$ & $\sqrt{ }$ & $\sqrt{ }$ & $\sqrt{ }$ & $\sqrt{ }$ & $\sqrt{ }$ & $\sqrt{ }$ & & \\
\hline TEM6 & $\sqrt{ }$ & $\sqrt{ }$ & $\sqrt{ }$ & $\sqrt{ }$ & $\sqrt{ }$ & $\sqrt{ }$ & $\sqrt{ }$ & \\
\hline VEGAS2 & $\sqrt{ }$ & $\sqrt{ }$ & $\sqrt{ }$ & $\sqrt{ }$ & $\sqrt{ }$ & $\sqrt{ }$ & & \\
\hline \multicolumn{9}{|c|}{ TRENDY } \\
\hline CLM4-CN & $\sqrt{ }$ & $\sqrt{ }$ & $\sqrt{ }$ & $\sqrt{ }$ & $\sqrt{ }$ & $\sqrt{ }$ & $\sqrt{ }$ & \\
\hline HYLAND & $\sqrt{ }$ & $\sqrt{ }$ & $\sqrt{ }$ & $\sqrt{ }$ & $\sqrt{ }$ & $\sqrt{ }$ & $\sqrt{ }$ & \\
\hline LPJwsl & $\sqrt{ }$ & $\sqrt{ }$ & $\sqrt{ }$ & $\sqrt{ }$ & $\sqrt{ }$ & $\sqrt{ }$ & $\sqrt{ }$ & \\
\hline LPJ-GUESS & $\sqrt{ }$ & $\sqrt{ }$ & $\sqrt{ }$ & $\sqrt{ }$ & $\sqrt{ }$ & $\sqrt{ }$ & $\sqrt{ }$ & \\
\hline $\mathrm{OCN}$ & $\sqrt{ }$ & $\sqrt{ }$ & $\sqrt{ }$ & $\sqrt{ }$ & $\sqrt{ }$ & $\sqrt{ }$ & $\sqrt{ }$ & \\
\hline ORCHIDEE & $\sqrt{ }$ & $\sqrt{ }$ & $\sqrt{ }$ & $\sqrt{ }$ & $\sqrt{ }$ & $\sqrt{ }$ & $\sqrt{ }$ & \\
\hline SDGVM & $\sqrt{ }$ & $\sqrt{ }$ & $\sqrt{ }$ & $\sqrt{ }$ & $\sqrt{ }$ & $\sqrt{ }$ & $\sqrt{ }$ & \\
\hline TRIFFID & $\sqrt{ }$ & $\sqrt{ }$ & $\sqrt{ }$ & $\sqrt{ }$ & $\sqrt{ }$ & $\sqrt{ }$ & $\sqrt{ }$ & \\
\hline VEGAS & $\sqrt{ }$ & $\sqrt{ }$ & $\sqrt{ }$ & $\sqrt{ }$ & $\sqrt{ }$ & $\sqrt{ }$ & $\sqrt{ }$ & \\
\hline \multicolumn{9}{|c|}{ WETCHIMP } \\
\hline CLM4Me & & & & & & & & $\sqrt{ }$ \\
\hline DLEM & & & & & & & & $\sqrt{ }$ \\
\hline LPJ-Bern & & & & & & & & $\sqrt{ }$ \\
\hline LPJ-WHyMe & & & & & & & & $\sqrt{ }$ \\
\hline LPJwsl & & & & & & & & $\sqrt{ }$ \\
\hline ORCHIDEE & & & & & & & & $\sqrt{ }$ \\
\hline SDGVM & & & & & & & & $\sqrt{ }$ \\
\hline \multicolumn{9}{|c|}{ NACP site } \\
\hline In situ (ATQ, BRW) & $\sqrt{ }$ & $\sqrt{ }$ & $\sqrt{ }$ & & & & & \\
\hline Can-IBIS & $\sqrt{ }$ & $\sqrt{ }$ & $\sqrt{ }$ & & & & $\sqrt{ }$ & \\
\hline CN-CLASS & $\sqrt{ }$ & $\sqrt{ }$ & $\sqrt{ }$ & & & & $\sqrt{ }$ & \\
\hline DLEM & $\sqrt{ }$ & $\sqrt{ }$ & $\sqrt{ }$ & & & & $\sqrt{ }$ & \\
\hline Ecosys & $\sqrt{ }$ & $\sqrt{ }$ & $\sqrt{ }$ & & & & $\sqrt{ }$ & \\
\hline LPJwsl & $\sqrt{ }$ & $\sqrt{ }$ & $\sqrt{ }$ & & & & $\sqrt{ }$ & \\
\hline ORCHIDEE & $\sqrt{ }$ & $\sqrt{ }$ & $\sqrt{ }$ & & & & $\sqrt{ }$ & \\
\hline $\mathrm{SiB}$ & $\sqrt{ }$ & $\sqrt{ }$ & $\sqrt{ }$ & & & & & \\
\hline SiBCASA & $\sqrt{ }$ & $\sqrt{ }$ & $\sqrt{ }$ & & & & $\sqrt{ }$ & \\
\hline $\mathrm{SSiB} 2$ & $\sqrt{ }$ & $\sqrt{ }$ & $\sqrt{ }$ & & & & & \\
\hline TECO & $\sqrt{ }$ & $\sqrt{ }$ & $\sqrt{ }$ & & & & $\sqrt{ }$ & \\
\hline
\end{tabular}

Notes: NEE includes NBP (all TRENDY models except HYLAND) and NEP (NACP regional: BEPS, Can-IBIS, CLM-CASA, CLM4-CN, VEGAS2; TRENDY: HYLAND). Re may be calculated from Rh + Ra (e.g., NACP regional) or NEE-GPP (all NACP regional except CASA-TRANSCOM and ISAM; all TRENDY). Ra may be calculated from NEE-GPP-Rh (NACP regional: BEPS, CLM-CASA, CLM4-CN, ORCHIDEE, TEM6; TRENDY: HYLAND, ORCHIDEE, VEGAS). NPP may be calculated from GPP-Ra (TRENDY: LPJ-GUESS). 


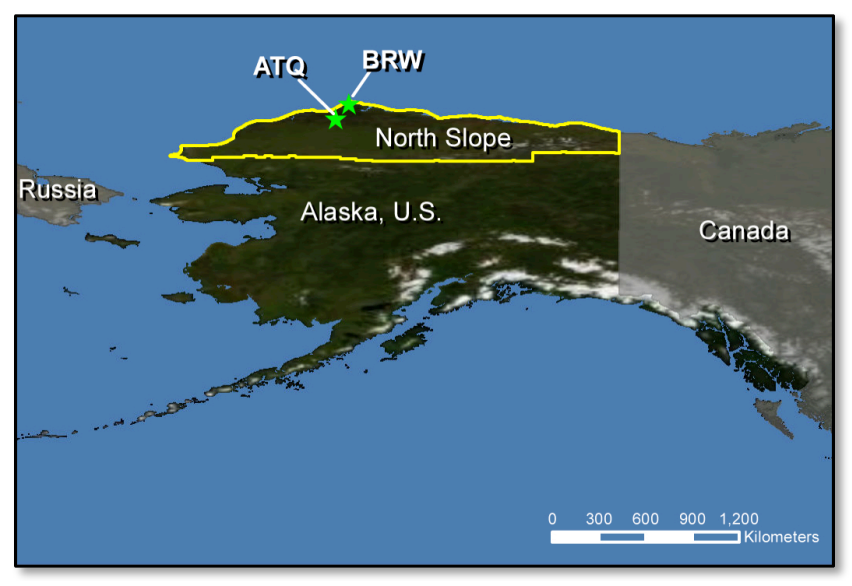

Figure 1. Map of the Alaskan Arctic North Slope delineation, and the two AmeriFlux sites used in this study (Atqasuk: ATQ; Barrow: BRW).

Variables assessed for NACP regional and TRENDY included: NEE, gross primary production (GPP), heterotrophic respiration $(\mathrm{Rh})$, autotrophic respiration $(\mathrm{Ra})$, net primary production (NPP), and soil carbon stock (Csoil). Some models provided GPP and NPP, but not Ra, while others provided GPP and Ra, but not NPP, so we were able to calculate the missing term in those equations with one unknown. $\mathrm{CH}_{4}$ was provided only from WETCHIMP models, and this is solely what we used the WETCHIMP models for. Most variables were identical across NACP regional and TRENDY, except that the net $\mathrm{CO}_{2}$ flux was reported as net biome production (NBP) for TRENDY (and net ecosystem production, NEP, for HYLAND only), whereas oppositely it was reported as NEE for NACP regional. We reversed the sign for TRENDY (and converted time units of seconds to months) to equate the $\mathrm{CO}_{2}$ flux between both MIPs, though we note that technically NBP should include additional fluxes from fire and other disturbances as well as lateral carbon transport that NEE would not include. Models LPJwsl and VEGAS from TRENDY were not converted because their values were already in the units of NACP. Models HYLAND and SDGVM in TRENDY reported net $\mathrm{CO}_{2}$ flux values in the incorrect sign so we reversed the sign.

We created a half-degree resolution mask of the state of Alaska and a mask of the North Slope (Fig. 1) used to clip from the global (TRENDY) and North America (NACP regional) model output. We transformed the masks to match the different native resolutions of the models. We produced mean annual maps for the state of Alaska for NEE, GPP, Rh, $\mathrm{Ra}$, NPP, and Csoil by averaging the available monthly model output and preserving the native spatial resolution for each model. We set a uniform color scale bar for between-model visual comparison (rather than individual scale bars for each model, which would highlight within-model spatial variability). However, in some the range was effectively truncated due to some large values beyond our set minimum/maximum of the scale; in other cases the minimum/maximum was wider than a given model's range, so spatial variation within that model may be difficult to visualize.

We produced maps for the multi-model mean $(\bar{x})$ and standard deviation $(\sigma)$ from the individual mean annual maps. Given non-uniform spatial resolutions across models, we present the multi-model $(\bar{x})$ and $\sigma$ at the finest resolution (i.e., $0.5^{\circ}$ ). We arithmetically downscaled all models with coarser resolutions to $0.5^{\circ}$. Pixels that overlapped with one another across models were used to calculate the individual half-degree pixel averages. Finally, we re-applied the half-degree mask of Alaska to the resultant multi-model $(\bar{x})$ and $\sigma$ maps (i.e., removing newly added beyond-coastal pixels from the combination of some wider-extent, coarse-scale models). The multi-model $(\bar{x})$ color scale bar was set equal to that of the individual model maps; the color scale bar for the $\sigma$ was set differently, tailored to the range of the $\sigma$. We also generated a time series plot from the spatial mean of all pixels in the Alaskan Arctic for each month for each model (except for Csoil, which did not vary temporally over our time domain).

While the MIPs enable us to conduct an extensive analysis, they also impose some limitations: (i) not all possible Terrestrial Biosphere Models (TBMs) are included in the MIPs (e.g. there are TBMs used in the scientific community that were not contributed); (ii) the models are not completely independent from one another, at times sharing similar physics for some processes, and with some contributing to multiple MIPs; (iii) the forcing data accuracy and variability were not assessed (though they were originally cross-checked and considered the best available); and (iiv) some models have more sophisticated representation of the biophysical processes important in the Arctic than others (though all TBMs produce Arctic estimates). Nonetheless, the data available for this analysis provide a representative range of information for calculating a baseline of uncertainty and variability in key environmental variables of the Alaskan Arctic. Overcoming some of the above limitations would allow improvements in the estimation of our baseline uncertainty.

\subsection{Site level}

We used model output from 10 NACP site synthesis models, which include: CanIBIS (El Maayar et al., 2002), CNCLASS (Arain et al., 2006), DLEM (Tian et al., 2010), Ecosys (Grant et al., 2009), LPJwsl (Sitch et al., 2003), ORCHIDEE (Krinner et al., 2005), SiB (Baker et al., 2008), SiBCASA (Schaefer et al., 2008), SSiB2 (Xue et al., 1991), and TECO (Weng and Luo, 2008). Model output for the NACP site synthesis was downloaded from: http:// isynth-site.pbworks.com/w/page/9422807/FrontPage. Models were provided with in situ measured forcing data for each site to produce site level (e.g., point) model estimates. 
In situ data from the Alaskan North Slope Atqasuk $\left(70.4696^{\circ} \mathrm{N},-157.4089^{\circ} \mathrm{W}\right)$ and Barrow $\left(71.3225^{\circ} \mathrm{N}\right.$, $-156.6259^{\circ} \mathrm{W}$ ) sites (Kwon et al., 2006) (Fig. 1) were modified from http://www.fluxdata.org (Agarwal et al., 2010) by adding the self-heating correction to all Atqasuk data (the "Burba" correction; Oechel et al., 2014). Data used for 2006 were from Oechel et al. (2014), which used the same correction as for the other available years. The in situ sites are part of the regional AmeriFlux network and global FLUXNET network where tower-based eddy covariance fluxes and micrometeorological variables are measured (Baldocchi, 2008). Half-hourly data were used to compute mean diurnal (from mean hourly) and seasonal (from mean monthly) cycles.

Atqasuk consists of moist-wet coastal sedge tundra and moist tussock tundra surfaces (e.g., Eriophorum vaginatum) in the well-drained upland (Oechel et al., 2014). Barrow consists of undisturbed wet-moist coastal sedge tundra types, multiple ice wedges, drained lake tundra land forms, and is located $2 \mathrm{~km}$ south of the Arctic Ocean and $100 \mathrm{~km}$ north of Atqasuk (Zona et al., 2010); the Alaskan coastal plain encompassing Barrow was generally not glaciated during the last period of glaciation. Atqasuk's more continental climate and sandy substrate make a useful contrast with conditions at Barrow (Kwon et al., 2006). Another Alaskan AmeriFlux eddy covariance ground site, Ivotuk, was operational; however, site-level model simulations were not available for this site.

To maintain consistency for fair comparison, when one data point was missing for either model or site, we removed all data points for that time step for all models and measurements; thus, the averages shown are not necessarily "true" averages for each model or measurements. Days were excluded if fewer than $12 \mathrm{~h}$ of data were available. We used the available in situ data to define our site level time domain: 2003-2006 for Atqasuk and 1998-2002 for Barrow. In situ data for Barrow were available only during the growing season (northern summer) for most years. Variables assessed included: NEE, GPP, Re, and Csoil. NACP processed files for NEE, GPP, and Re were used for analysis; original/raw NetCDF (Network Common Data Form; nc) files were used for all other variables. Raw files for ORCHIDEE had to be time shifted by $9 \mathrm{~h}$; leap years were adjusted for ORCHIDEE and LPJwsl. Not all models or sites provided data for all variables. Models did not provide diurnally or seasonally varying site level Csoil so analysis of Csoil was done at the annual timescale only.

To link the site measurements to the regional model patterns, we evaluated the correlation structure between NEE and GPP or Re at the sites versus the region. That is, we calculated the $r^{2}$ for NEE vs. GPP and NEE vs. Re. This was done for the site measurements and for each model at the regional level. We then evaluated how well the regional models matched the site level correlation patterns.

To provide a spatial picture of how representative the sites are to the larger region, we constructed statewide site representativeness maps based on statewide spatially explicit climatology using the incremental analysis updates (IAU) 2-D atmospheric single level diagnostics (near surface air temperature) and IAU 2-D land-surface diagnostics (precipitation) from the Modern Era Retrospective Analysis for Research and Applications (MERRA) generated by NASA's Global Modeling and Assimilation Office (GMAO) at $0.5 \times 0.66^{\circ}$ resolution (Rienecker et al., 2011). MERRA data were downloaded from: http://disc.sci.gsfc.nasa.gov/ daac-bin/DataHoldings.pl?LOOKUPID_List=MAT1NX*** (where *** is "SLV" or "LND" for air temperature and precipitation, respectively). We compared the mean daily time series of site level air temperature and precipitation for 2001 (i.e., the year that both sites overlapped, for comparison; flux data were not available at Atqasuk for 2001) against the corresponding time series of the MERRA data for each pixel in Alaska, computing the correlation coefficient $\left(r^{2}\right)$ for each pixel (e.g., variability representativeness). We removed MERRA data for time steps where there were data gaps from the in situ data. We adjusted the time zones between the in situ data and MERRA (i.e., Alaskan Standard Time, AST; Greenwich Mean Time, GMT, respectively) to match. We converted units of air temperature from Kelvin (MERRA) to Celsius (in situ), and units of precipitation from mm (in situ) to $\mathrm{kg} \mathrm{m}^{-2} \mathrm{~s}^{-1}$ (MERRA) to match.

\section{Results}

The Results are partitioned into five sub-sections: (I) spatial variability; (II) temporal variability; (III) an integrated summary; (IV) sensitivity analysis; and (V) site level evaluation.

\subsection{Spatial variability in carbon}

The spatial patterns in mean annual NEE for statewide Alaska (Arctic and boreal region) varied widely among the models, essentially showing no consistency, with almost all patterns having at least one other model showing the opposite pattern (Fig. 2; data for a single year, 2003, are shown for example, though these relative patterns remain for other years). Some models showed the entire region as a strong carbon sink, others as a strong carbon source, while still others as close to carbon neutral. Some models showed a large portion of the region as a carbon sink with the rest of the state a carbon source; other models showed the opposite pattern of source and sink distribution. It is also visually apparent that the spatial resolutions vary widely among models (i.e., $0.5 \times 0.5^{\circ}-2.5 \times 3.75^{\circ}$ ). The multi-model mean annual NEE for Alaska shows the region as largely carbon neutral (Fig. 3a). This contradicts some observations that show the region to be an overall source of $\mathrm{CO}_{2}$ to the atmosphere (Oechel et al., 2000, 2014). The multi-model annual NEE $\sigma$ for Alaska shows model agreement or disagreement 

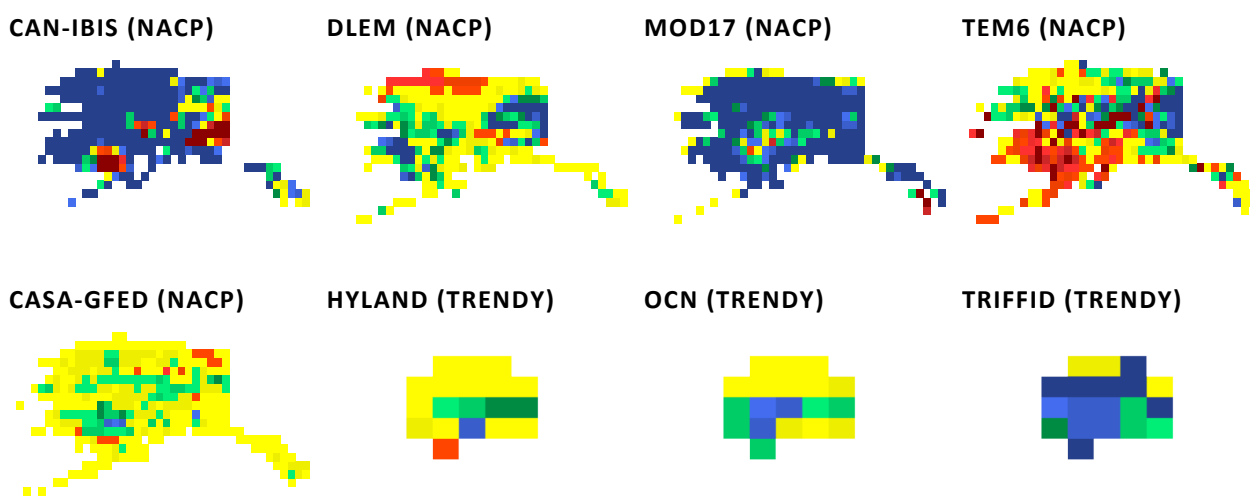

HYLAND (TRENDY)

OCN (TRENDY)

TRIFFID (TRENDY)
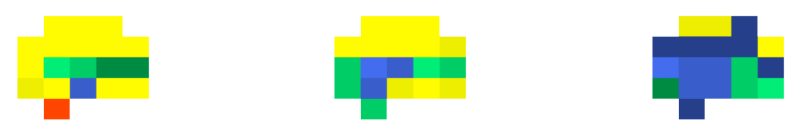

CASA-TRANSCOM (NACP) ISAM (NACP)

ORCHIDEE (NACP)

VEGAS (TRENDY)
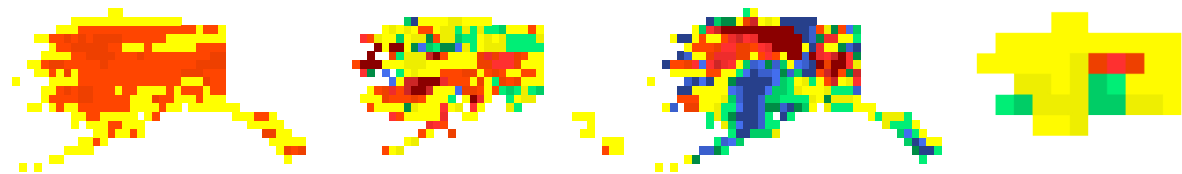

CLM-CASA (NACP)

LPJ-GUESS (TRENDY)

ORCHIDEE (TRENDY)

VEGAS2 (NACP)
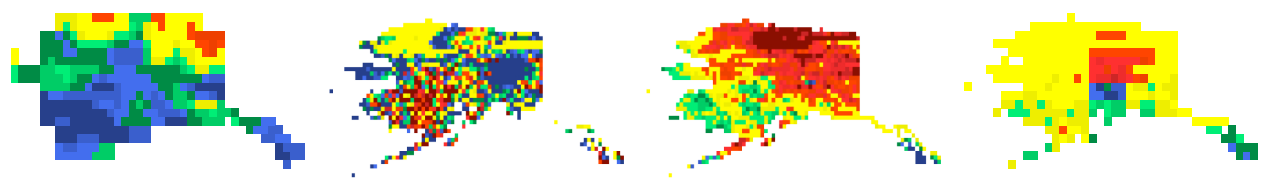

CLM4-CN (NACP)

LPJwsI (NACP)

SDGVM (TRENDY)

BEPS (NACP)
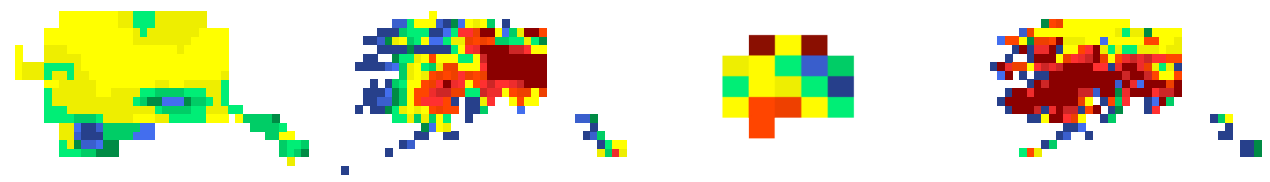

CLM4-CN (TRENDY)

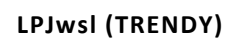

SiB3 (NACP)
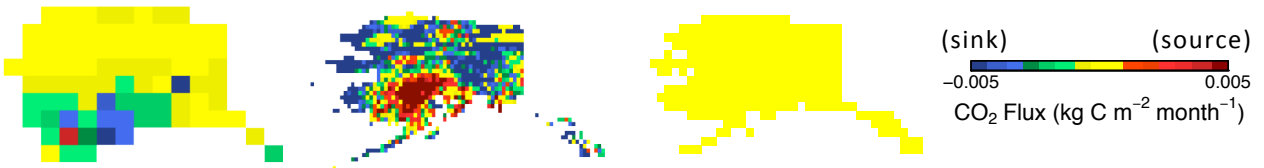

Figure 2. Mean annual (2003) net $\mathrm{CO}_{2}$ flux for Alaska. Model output was part of the TRENDY (common forcing) and NACP regional (variable forcing) syntheses.

distributed throughout the region, with greater agreement in boreal regions than in tundra regions (Fig. 3b).

In the Supplement figures, we provide the same spatial diagnostics for the carbon components that comprise NEE, that is, GPP, NPP, Rh, and Ra (Figs. S1-8).
For $\mathrm{CH}_{4}$, fluxes were primarily present and largest in the southernmost regions of Alaska (Figs. 4 and 5a). Most model disagreement was along the southwest Alaska Peninsula/southeast Alaska Panhandle (Fig. 5b). There was also significant disagreement as to whether or not $\mathrm{CH}_{4}$ fluxes occur at all in the interior of Alaska. Models such as DLEM (Tian et al., 2014) and ORCHIDEE estimated no interior $\mathrm{CH}_{4}$ flux whereas LPJ-WHyMe, LPJ-Bern, and SDGVM estimated moderate to high fluxes of $\mathrm{CH}_{4}$. The spatial differences in $\mathrm{CH}_{4}$ fluxes among models are primarily due to differences in wetland location schemes in the models, soil temperature and freeze/thaw sensitivity, and the magnitude of the 
a) Multi-Model (23) Mean $\mathrm{CO}_{2}$ Flux

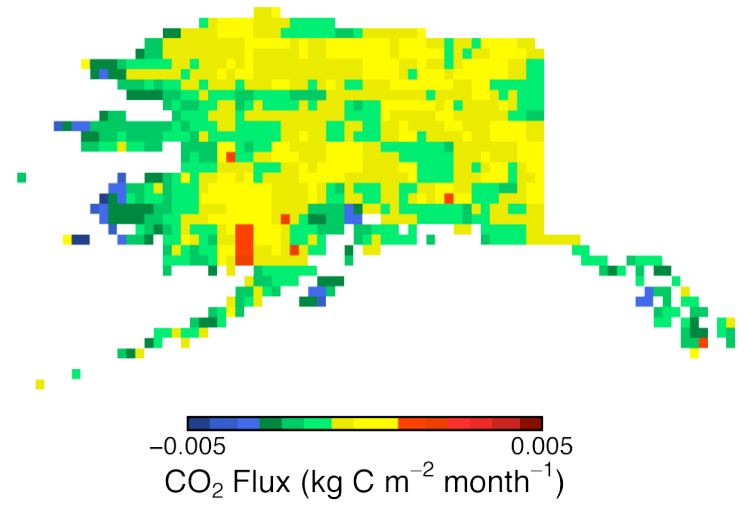

b) Standard Deviation

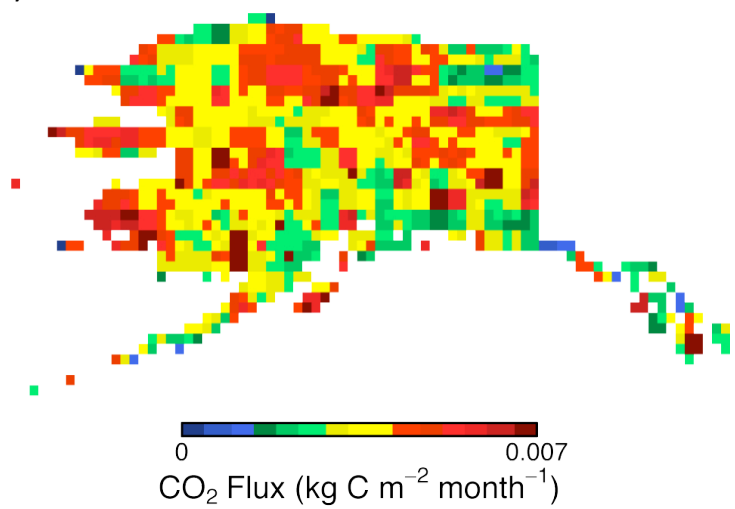

Figure 3. NACP and TRENDY multi-model $(n=23)$ net $\mathrm{CO}_{2}$ flux for 2003 (a) mean, and (b) standard deviation.

fluxes is due to the vegetation dynamics and soil maps used in the models (Olefeldt et al., 2013). Models LPJ-WHyMe and LPJ-Bern both used the same peatland database to determine peatland locations (the two models also contain similar code structures), which gives them more central $\mathrm{CH}_{4}$ producing regions, though they are not identical because of differences in inundation thresholds and wet mineral soils leading to $\mathrm{CH}_{4}$ fluxes. Models DLEM, ORCHIDEE, LPJwsl, and CLM4Me all are driven with or are parameterized from an inundation data set, which provided a bias away from interior $\mathrm{CH}_{4}$-producing regions. Model SDGVM calculates the wetlands extent independently, somewhat similar to the wet soils parameterization in LPJ-Bern.

Total soil carbon for the Alaskan Arctic (North Slope) varied from 1.4 to $29.3 \mathrm{~kg} \mathrm{C} \mathrm{m}^{-2}$ across models (Fig. 6), with a multi-model mean of $14.0 \mathrm{~kg} \mathrm{C} \mathrm{m}^{-2}$ and $\sigma$ of $9.2 \mathrm{~kg} \mathrm{C} \mathrm{m}^{-2}$. We provide the spatial diagnostics for soil carbon in Supplement Fig. S9 (individual models) and Fig. S10 (multi-model mean and standard deviation). There was no clear spatial pattern similarity across models in soil carbon, with the greatest multi-model uncertainty throughout the permafrost areas in the north.

\subsection{Temporal variability in carbon}

The mean Alaskan Arctic (North Slope) time-varying NEE for each model was generally similar in timing across models, showing carbon sinks in the short growing season, separated by carbon sources in the winter that represented lower rates but over a longer period (Fig. 7; we show two years for comparison, 2002-2003, though the relative patterns remain for other years). The multi-model de-trended (from the multimodel mean) $\sigma$ was $0.01 \mathrm{~kg} \mathrm{C} \mathrm{m}^{-2} \mathrm{yr}^{-1}$. The multi-model mean month of greatest $\mathrm{CO}_{2}$ uptake was July, with a $\sigma$ of 0.5 months.

In the Supplement figures, we provide the same time series plots for the carbon components that comprise NEE (GPP, NPP, Rh, and Ra; Figs. S11-14). Of particular note is the considerable variability among models in their estimates of $\mathrm{Rh}$ during the winter (November-March) (Fig. S13), when all other flux components minimized to zero during this "dormant" period (i.e., November-March). This pattern was corroborated by a recent analysis of winter Rh (between 0-20\% of annual Rh) in similar ecosystems (Wang et al., 2011). The winter carbon source is also seen as integrated into the time series of NEE in Fig. 7.

The time series for $\mathrm{CH}_{4}$ in the Alaskan Arctic (North Slope) showed similar temporal patterns for most of the models with $\mathrm{CH}_{4}$ flux emissions year round for many models (Fig. 8). The multi-model mean month of greatest $\mathrm{CH}_{4}$ emission was August for both years, with a $\sigma$ of 1.4 months. The variability in timing of greatest $\mathrm{CH}_{4}$ emission was nearly three times that of greatest $\mathrm{CO}_{2}$ uptake, indicating large uncertainty in $\mathrm{CH}_{4}$ flux timing relative to that of $\mathrm{CO}_{2}$, presumably because the climatic controls on photosynthesis (light and temperature) constrain the period of greatest $\mathrm{CO}_{2}$ uptake more narrowly than the combination of temperature and soil moisture that would be likely to affect the modeled seasonal maximum $\mathrm{CH}_{4}$ release.

Seasonal patterns were negligible for soil carbon (e.g., relatively constant throughout each year) so these are not shown.

\subsection{Summary of carbon uncertainties}

From a total carbon perspective, the largest quantity of absolute $\sigma$ for the Alaskan Arctic (North Slope) was in soil carbon, followed by GPP, Re, NPP, Ra, Rh, NEE, and $\mathrm{CH}_{4}$ (Fig. 9). Proportionally for the gross fluxes (i.e., excluding NEE and NPP), the largest relative (as opposed to absolute) uncertainty was in $\mathrm{Ra}$ at $226 \%(0.09 \pm 0.20 \mathrm{~kg} \mathrm{C}$ $\left.\mathrm{m}^{-2} \mathrm{yr}^{-1}\right)$, GPP at $225 \%\left(0.22 \pm 0.50 \mathrm{~kg} \mathrm{C} \mathrm{m}^{-2} \mathrm{yr}^{-1}\right)$, Re at $169 \%\left(0.23 \pm 0.38 \mathrm{~kg} \mathrm{C} \mathrm{m}^{-2} \mathrm{yr}^{-1}\right), \mathrm{CH}_{4}$ flux at $160 \%$ $\left(2.52 \pm 4.02 \mathrm{~g} \mathrm{CH}_{4} \mathrm{~m}^{-2} \mathrm{yr}^{-1}\right)$, Rh at $149 \%(0.14 \pm 0.20 \mathrm{~kg}$ $\left.\mathrm{C} \mathrm{m}^{-2} \mathrm{yr}^{-1}\right)$, and soil carbon at $66 \%\left(14.0 \pm 9.2 \mathrm{~kg} \mathrm{C} \mathrm{m}^{-2}\right)$. 


\section{CLM4Me}

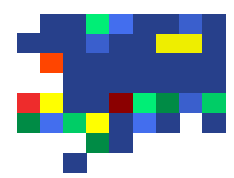

LPJ-Bern

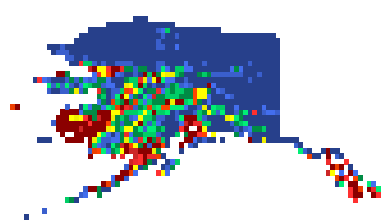

LPJwsI

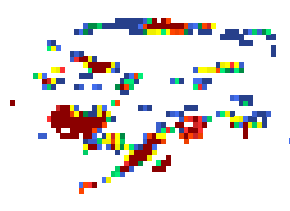

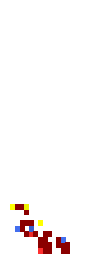

SDGVM

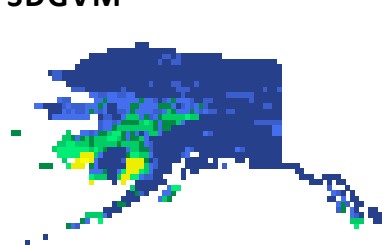

DLEM

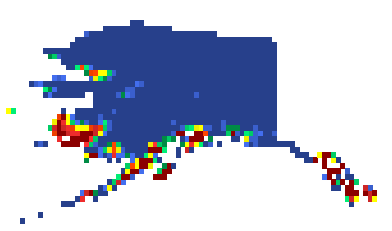

LPJ-WhyMe

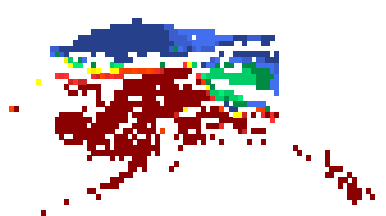

ORCHIDEE

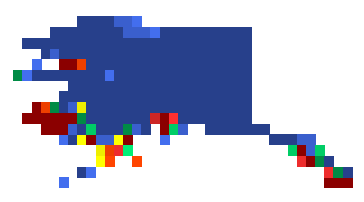

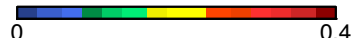

$\mathrm{CH}_{4}$ Flux (g CH4 m ${ }^{-2}$ month $^{-1}$ )

Figure 4. Mean annual (2003) net $\mathrm{CH}_{4}$ flux for Alaska. Model output was part of the WETCHIMP model intercomparison project.

a) Multi-Model (7) Mean $\mathrm{CH}_{4}$ Flux

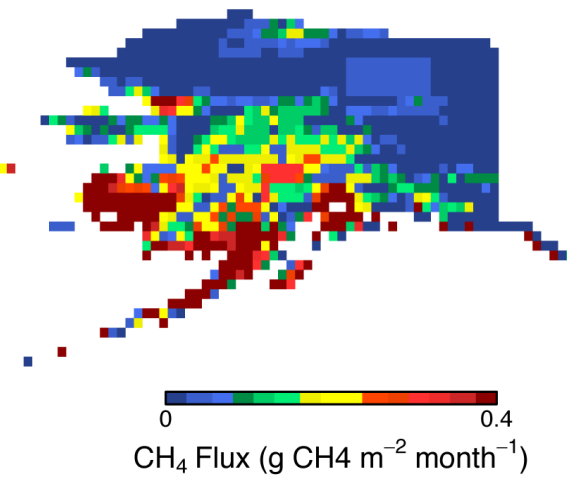

b) Standard Deviation

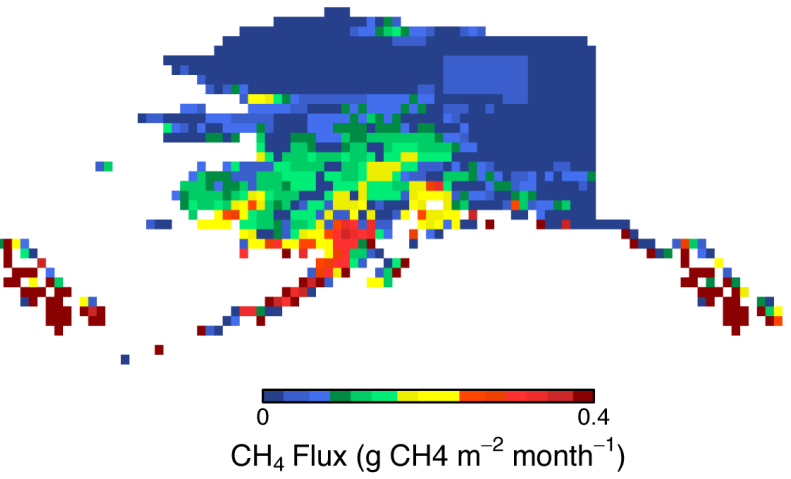

Figure 5. WETCHIMP multi-model $(n=7)$ net $\mathrm{CH}_{4}$ flux for 2003 (a) mean and (b) standard deviation.

\subsection{Site level evaluation}

To compare against measured carbon fluxes and soil carbon stocks, we present results from two sites located in the North Slope of Alaska - Atqasuk and Barrow - where a subset of models (NACP site) were run using in situ forcing data. First, to understand how representative the sites were to the larger region in lieu of a comprehensive spatial sampling study, we conducted a comparison of climatology at each site to that in each pixel, encompassing all of Alaska (Fig. S15). The expectation was that pixels closer to the sites would exhibit greater similarity in climatology, and this similarity would degrade following some linear or non-linear pattern within increasing distance away from the sites. Variability in climate was better represented in Atqasuk than Barrow relative to the wider region, which reinforces the conclusion that Atqasuk represents a more continental climate than does Barrow (Kwon et al., 2006).

Relative to in situ measured NEE, models did not capture the seasonal cycle well at either site (Fig. 10ab). Nonetheless, observed NEE tended to be contained within the multi- model uncertainty, which gives some indication that the regional uncertainty (e.g., in Fig. 7) may also bracket the true signal of NEE. The mean model seasonal $r^{2}$ was 0.13 at Atqasuk and 0.50 at Barrow (both-site mean: 0.32). The mean model seasonal RMSE was more similar than the $r^{2}$ between sites, with $0.41 \mu \mathrm{mol} \mathrm{CO}_{2} \mathrm{~m}^{-2} \mathrm{~s}^{-1}$ at Atqasuk and $0.46 \mu \mathrm{mol} \mathrm{CO}_{2} \mathrm{~m}^{-2} \mathrm{~s}^{-1}$ at Barrow (both-site mean: $0.44 \mu \mathrm{mol} \mathrm{CO}_{2} \mathrm{~m}^{-2} \mathrm{~s}^{-1}$ ). The multi-model monthly mean $\mathrm{NEE}$ and $\sigma$ were $-0.03 \pm 0.64 \mu \mathrm{mol} \mathrm{CO}_{2} \mathrm{~m}^{-2} \mathrm{~s}^{-1}$ at Atqasuk and $-0.04 \pm 0.54 \mu \mathrm{mol} \mathrm{CO}_{2} \mathrm{~m}^{-2} \mathrm{~s}^{-1}$ at Barrow.

The greatest observed $\mathrm{CO}_{2}$ uptake at Atqasuk was typically in June, whereas the multi-model mean placed the greatest $\mathrm{CO}_{2}$ uptake in July. For Barrow, the month of greatest observed $\mathrm{CO}_{2}$ uptake was typically July or August, and the multi-model mean tended to capture that timing accurately. This evaluation may extend into the regional analysis, indicating that the models likely capture the peak seasonal NEE timing, though possibly with a slight time lag. It is noted that the "observed" data presented here are not necessarily accurate representations of the actual in situ 


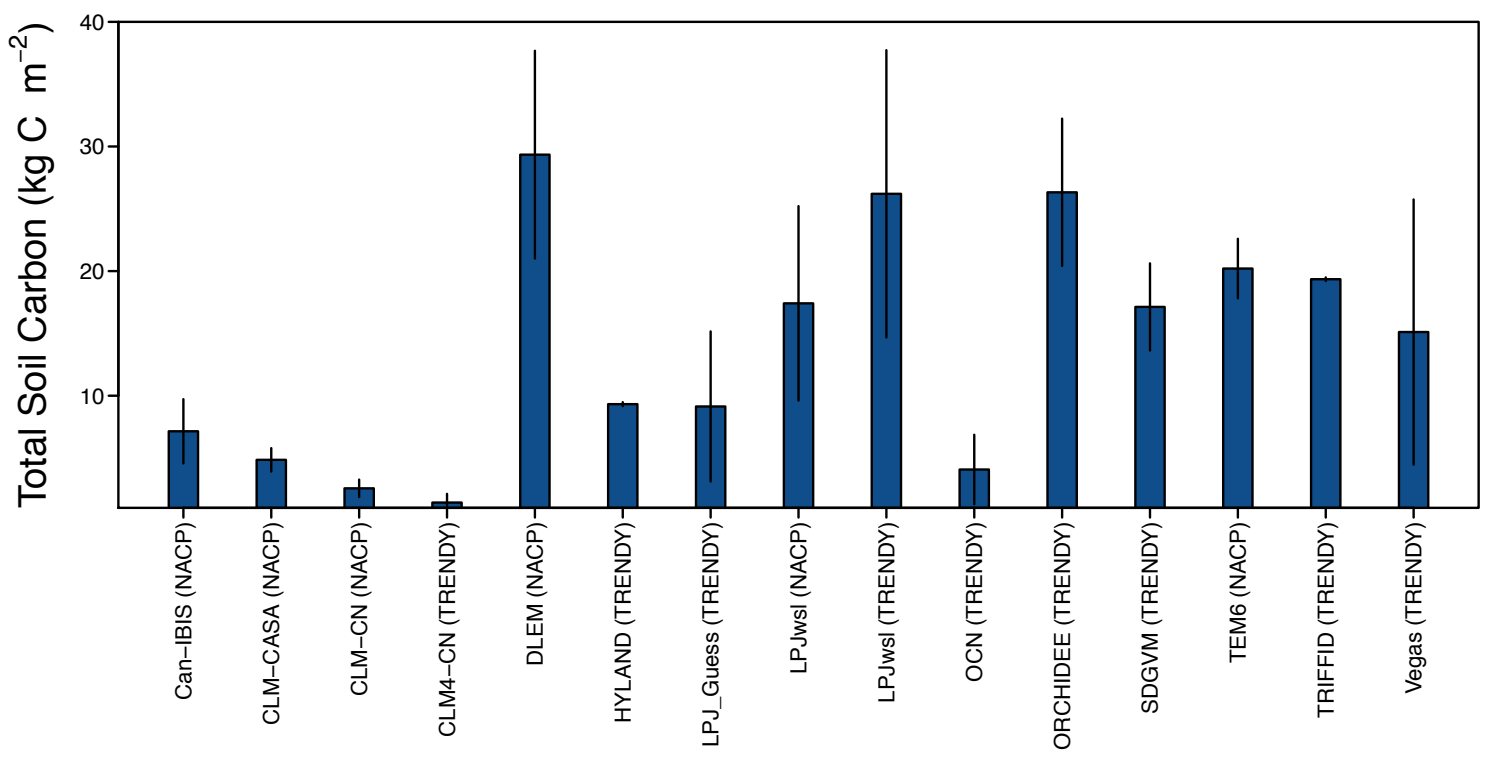

Figure 6. Mean annual Alaskan Arctic (North Slope) total soil carbon with spatial standard deviations.

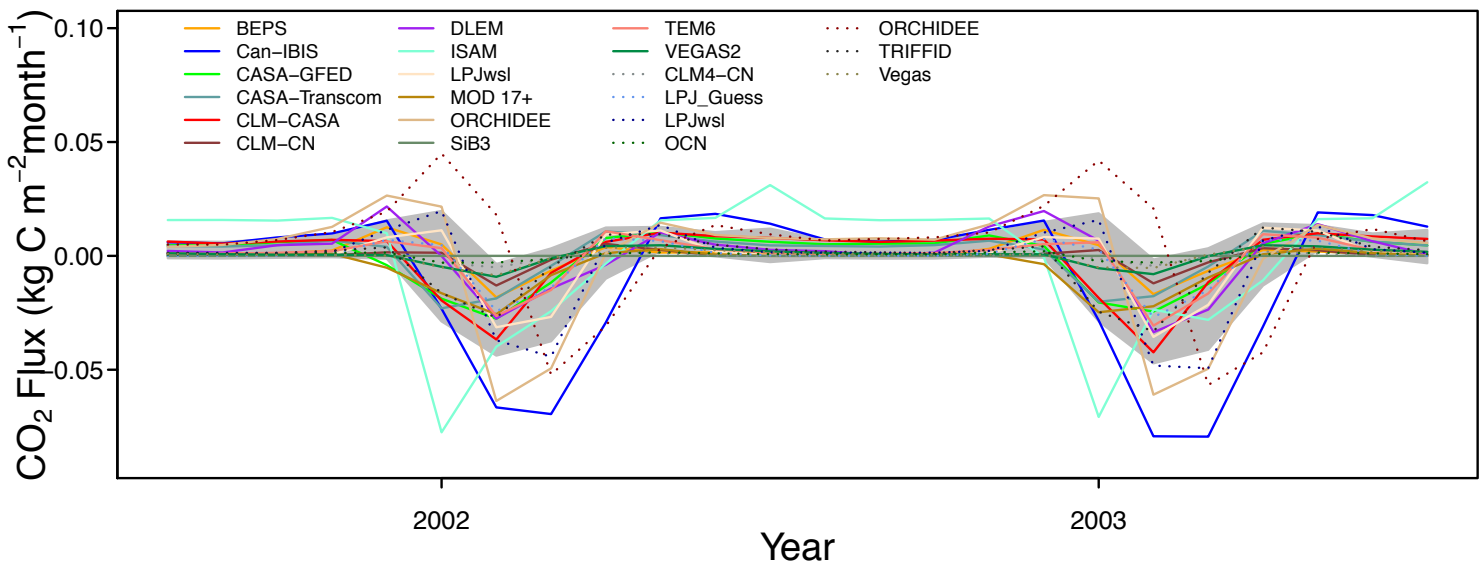

Figure 7. Mean monthly net $\mathrm{CO}_{2}$ flux for the Alaskan Arctic (North Slope), showing two years for example (2002-2003). NACP models are shown as solid lines and TRENDY models as dashed lines. The gray area is the multi-model standard deviation.

patterns because of our data-removal rule of matching models to data (see Sect. 2).

To understand how well the regional models capture the dynamics partitioning NEE into GPP and Re, we evaluated the factorial correlation structure between these carbon fluxes at the site level and compared that structure to the same correlation structure for each model at the regional level (North Slope). NEE at both sites was more correlated with GPP $(0.51)$ than with $\operatorname{Re}(0.24)$, with the correlation being 2.1 times greater for GPP than Re. Across all regional models, the multi-model mean NEE-to-GPP $r^{2}(0.77)$ was also 1.6 times larger than that for NEE-to-Re $(0.50)$, indicating the models were able to capture the differences in NEE partitioning between GPP and Re at the regional level along a similar partitioning structure as that at the site level, though the models had stronger NEE correlations with both GPP and $\mathrm{Re}$, and not as much separation.

\section{Discussion}

The objective of this analysis was to compile and quantify predictive uncertainty in terrestrial carbon cycle dynamics for Alaska, focusing on statistical quantification for the Alaskan Arctic (North Slope) but providing regional maps as well. Using a large sampling of terrestrial process models for the region, we evaluated the uncertainties contributing to divergent model results, and the resultant multimodel variability in carbon flux/stock estimation. We also evaluated patterns at the site level in the Alaskan Arctic against the regional patterns of the North Slope. As expected, 


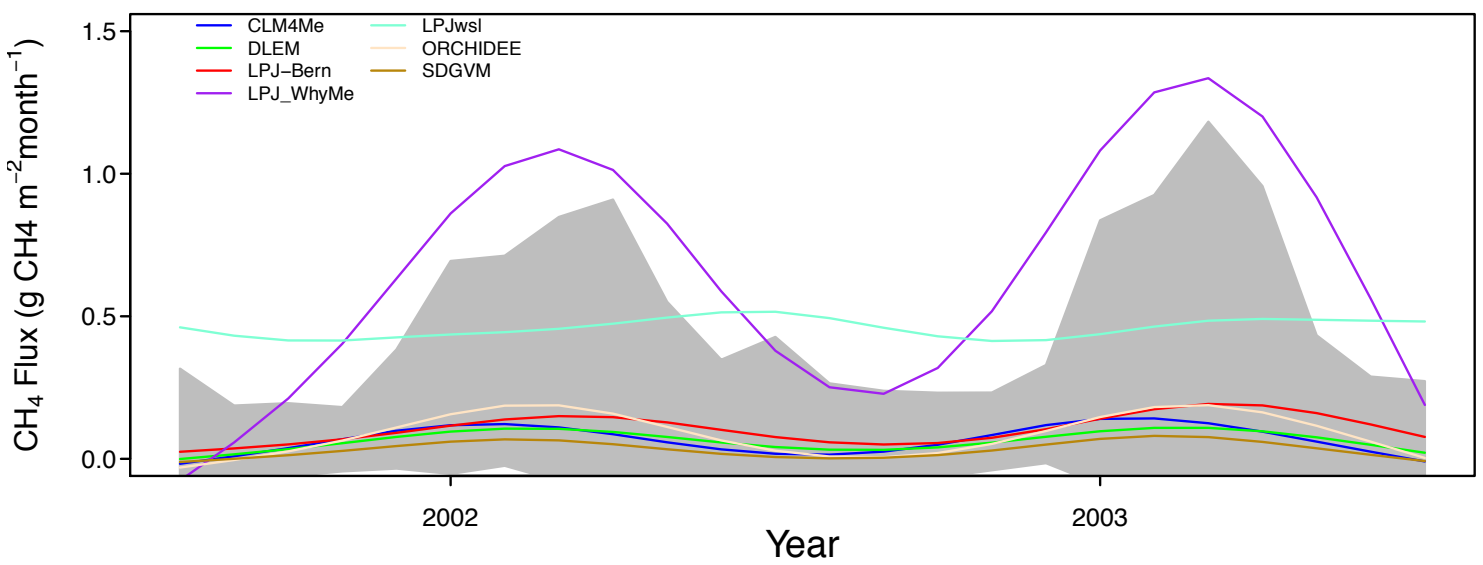

Figure 8. Mean monthly net $\mathrm{CH}_{4}$ flux for the Alaskan Arctic (North Slope), showing two years for example (2002-2003). The gray area is the multi-model standard deviation.

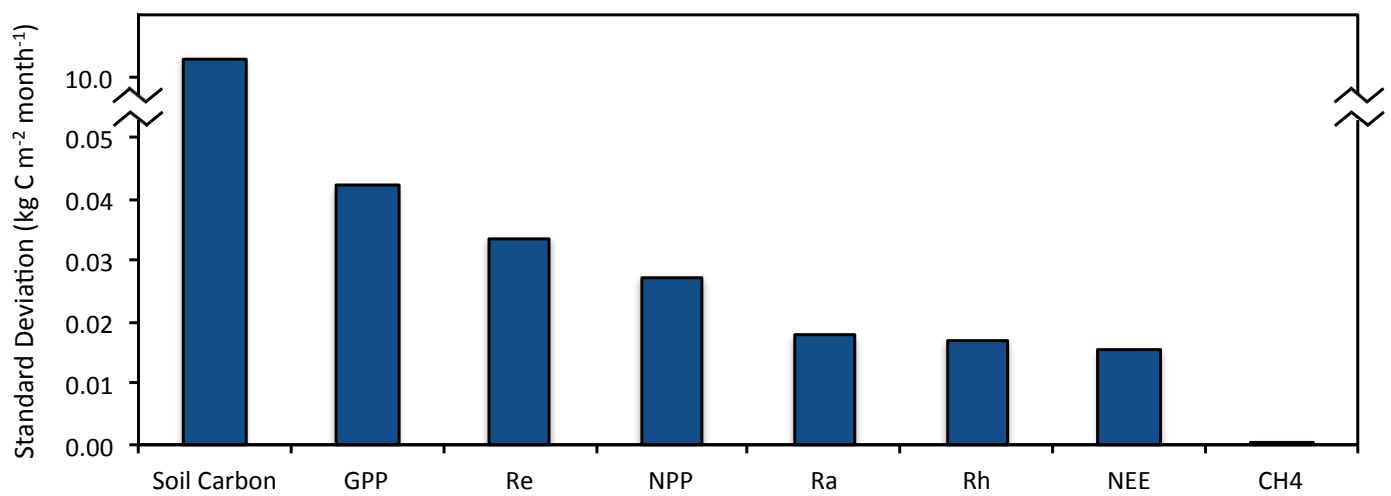

Figure 9. Multi-model uncertainty for all carbon components in the Alaskan Arctic (North Slope): (1) net ecosystem exchange (NEE) of $\mathrm{CO}_{2}$ between land and atmosphere; (2) net primary production (NPP); (3) autotrophic respiration (Ra); (4) gross primary production (GPP); (5) total ecosystem respiration (Re); (6) $\mathrm{CH}_{4}$ flux; (7) heterotrophic respiration (Rh); and (8) soil carbon.

spatial and temporal uncertainties in carbon fluxes and stocks were large, but we have now quantified in a rigorous and community-inclusive approach the numerical uncertainties in carbon cycle dynamics for Alaska. These have not been previously reported. It was important to compare the model outputs to actual measurements at co-located Alaskan Arctic AmeriFlux sites to extend the uncertainty analysis further from simply model-model variability to model-data agreement/disagreement. The large variation between measurement and model output is significant and noteworthy. However, it is important to note that as more eddy covariance flux sites are included, model-data comparison could converge or further diverge. At the moment, conclusions on the comparison of model and eddy covariance flux data are limited by the limited number of flux sites compared, and because significant areas of tundra are not represented by the tower data used in this comparison. Our analysis of site representation (Fig. S15) showed critical areas not well represented by these sites. This analysis should help inform decisions for upcoming field campaigns in the re- gion. These results are fundamental to future research in the Alaskan Arctic and boreal region to reduce uncertainties in the Arctic and boreal carbon cycle.

While uncertainty in carbon fluxes dominated, there was also significant disagreement in modeled soil carbon stocks, suggesting a major area of focus for model development given the potential impact of mobilized Arctic soil carbon with climate change (Billings et al., 1982; Burke et al., 2012; Christensen et al., 2004; Hayes et al., 2011; Koven et al., 2011; McGuire et al., 2009; Oechel et al., 1993, 1997; Oechel and Vourlitis, 1994; Schaefer et al., 2011; Schuur and Abbott, 2011; Schuur et al., 2008, 2009, 2013; Zimov et al., 2006). Soil carbon uncertainty leads directly to uncertainties in $\mathrm{CO}_{2}$ and $\mathrm{CH}_{4}$ fluxes as the primary carbon source for those fluxes (i.e., $\mathrm{Rh}$ for $\mathrm{CO}_{2}$ ). Model uncertainty in soil carbon is primarily because the basic paradigm of simple soil carbon modeling is vulnerable to the relatively highly heterogeneous soil physical environments - essentially a scatter of microscale frozen or unfrozen environments - some of which favor preservation of organic $\mathrm{C}$ much more than others. As 
a) Atqasuk

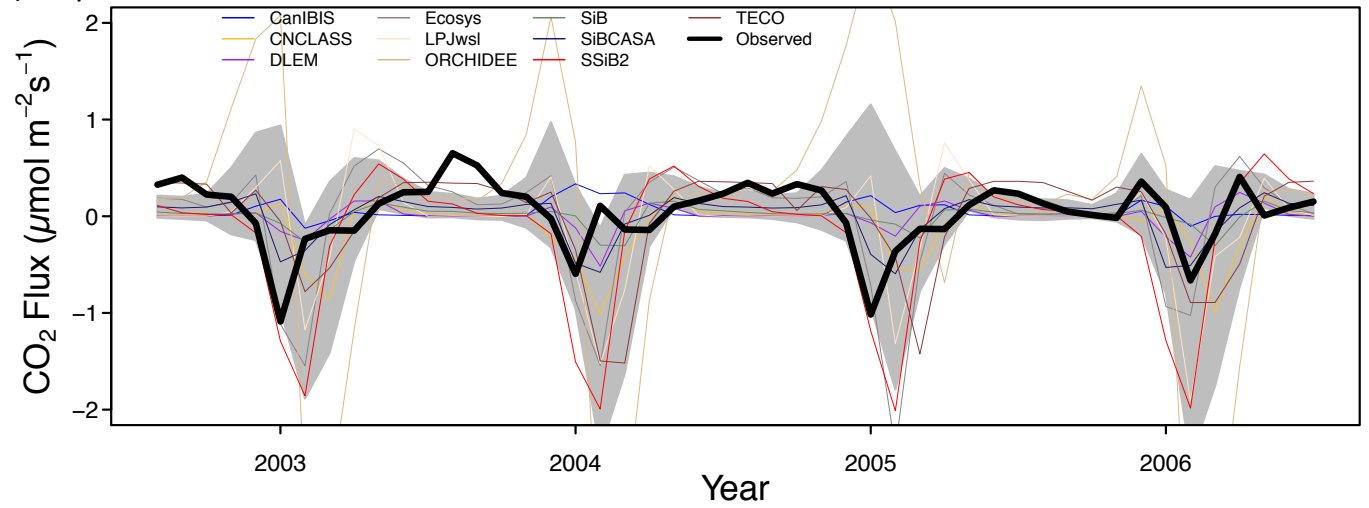

b) Barrow

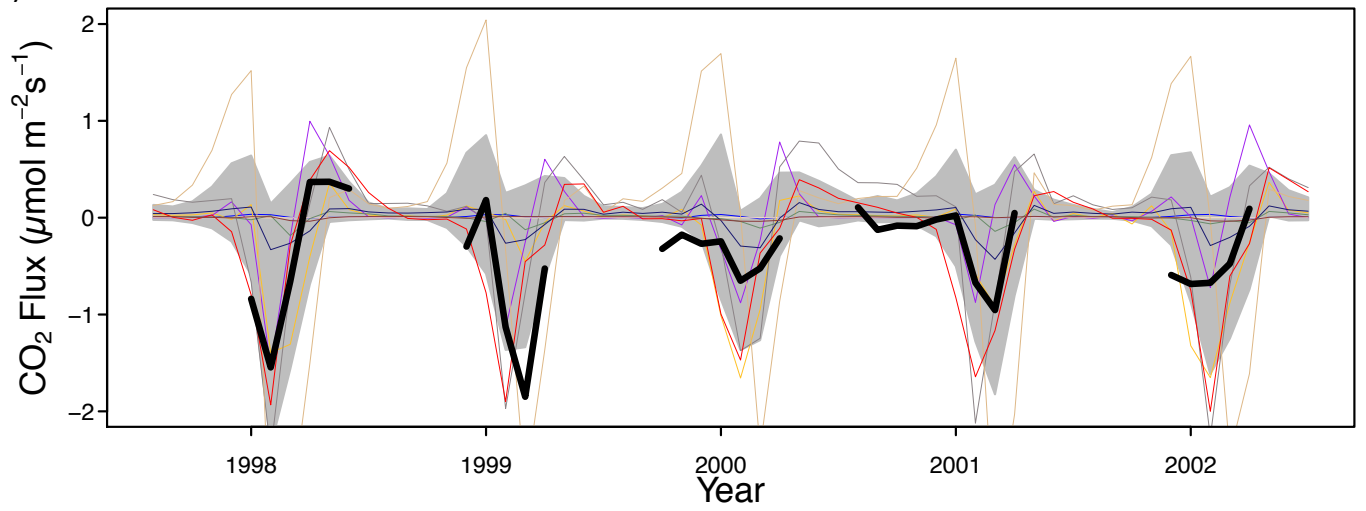

Figure 10. Mean monthly net $\mathrm{CO}_{2}$ flux for two sites in the Alaskan Arctic: (a) Atqasuk and (b) Barrow. The gray area is the multi-model standard deviation.

such, environmentally determined turnover can vary by orders of magnitude within the top meter of soil. Moreover, most models do not represent well the fast and slow storage and turnover rates of soil carbon with depth. In our analysis, soil carbon typically increased with NPP across the wider Alaskan region: soil carbon increased by $1 \mathrm{~kg} \mathrm{C} \mathrm{m}^{-2}$ for every $0.02 \mathrm{~kg} \mathrm{C} \mathrm{m}^{-2} \mathrm{yr}^{-1}$ increase in NPP $\left(r^{2}=0.64\right.$; $p<0.05$ ), corresponding to a bulk turnover time of 3 years if in equilibrium. Total soil carbon for the Alaskan Arctic (North Slope) varied from 1.4 to $29.3 \mathrm{~kg} \mathrm{C} \mathrm{m}^{-2}$ across models. This range of model estimates contrasts with the latest observation-based soil carbon assessments from recent Arctic/Alaska soil carbon syntheses, showing soil carbon ranges from 35 to $70 \mathrm{~kg} \mathrm{C} \mathrm{m}^{-2}$ total (Hugelius et al., 2013; Johnson et al., 2011; Mishra and Riley, 2012; Ping et al., 2008; Tarnocai et al., 2009).

A unique feature of our analysis is the comparison of NACP regional and TRENDY model runs, for which the latter used common forcing data unlike the former. A fundamental question with MIPs is posed: what is more important - the forcing data or the model physics? TRENDY prescribed historical climate and $\mathrm{CO}_{2}$ trends to the SDGVM so that the carbon sink/source is caused by a local imbalance between
GPP and $\mathrm{Re}$, given the residence time of $\mathrm{C}$ in pools. NACP, on the other hand, asked modelers to provide their "best regional flux estimates", and many models did not perform any spin up or historical simulations. We might expect TRENDY models to have larger carbon sinks than the NACP models. We also might expect that the TRENDY models would group together given that they shared common forcing data, unlike the NACP regional models; however, our results show no grouping of TRENDY or NACP models across variables, space, time, and relative values. Thus, for our study, variability in model output was driven primarily by differences in model physics rather than differences in forcing data. This observation may be more rigorously quantified with further analysis (e.g., cluster, geostatistical regression) (Mueller et al., 2010; Mueller et al., 2011; Poulter et al., 2011; Yadav et al., 2010).

Another type of grouping can be in the form of model "skill", or expected model skill in the region. Many modelers have focused development efforts targeting Arctic processes, so these models would be expected to have better, or at least similar, skill in our Arctic-focused analysis. Still, it would be subjective to draw those cut-offs between groups, not a task we could justifiably defend. Nonetheless, as a simple thought 
exercise, if we assess a few models that have demonstrated recent development in Arctic processes - TEM6 (Hayes et al., 2011; McGuire et al., 2009), CLM4-CN (Riley et al., 2011a), and ORCHIDEE (Koven et al., 2011) - one might expect that these models would group together. However, these models show no convergence (Fig. 2): TEM6 shows a carbon sink in the northeast and source in the southeast, ORCHIDEE shows the opposite of TEM6, and CLM4-CN has Alaska as largely carbon neutral.

In a similar vein, the "skill" of SiB3 was among the worst of all models in this analysis, showing little variability in space and time. One might be quick to discard such a model from intercomparisons, assuming that the model itself is simply of poor quality. The poor skill is somewhat surprising, however, as SiB3 was one of the best performing models in the Large-Scale Biosphere-Atmosphere Experiment in Amazonia Data-Model Intercomparison (LBADMIP) (de Gonçalves et al., 2013) - a region of arguably equivalent if not greater difficulty in model representation. But regional intercomparisons such as the one here prompt model developers to improve their models, especially for challenging bioclimatic conditions; exclusion would have inhibited model development progress and further reduction in uncertainty. For SiB3, the internal stress factors were too sensitive to the cold temperatures, disallowing the other (potentially very good) soil and plant processes to be activated. The model, as developed, had not anticipated frozen soils below the root zone $(1 \mathrm{~m})$, as well as mid-summer freezing, yet the soil water stress factor incorporated the entire soil column, thereby inflating the amount of stress imposed on plants, exacerbated by the extreme cold air temperature stress (Sellers et al., 1992). Since this analysis, the SiB3 developers have corrected this over-sensitivity. It is likely that other modelers will use this analysis, as well as the lesson learned from $\mathrm{SiB} 3$, to carefully evaluate their stress sensitivities and representations.

Our results are presented specifically to be applicable for use and comparison to a number of past and current largescale field campaigns: the Arctic Boundary Layer Expedition (ABLE; NASA), the Boreal Ecosystem-Atmosphere Study (BOREAS; NASA), the Arctic Research of the Composition of the Troposphere from Aircraft and Satellites (ARCTAS; NASA), Carbon in Arctic Reservoirs Vulnerability Experiment (CARVE; NASA), the Arctic Boreal Vulnerability Experiment (ABoVE; NASA), and the Next Generation Ecological Experiment (NGEE Arctic; US Department of Energy). The Arctic Boundary Layer Expedition integrated ground-based, aircraft, and satellite platforms focusing on characterization of tropospheric chemistry (Harriss et al., 1994). The Boreal Ecosystem-Atmosphere Study was a multi-scale campaign that laid the foundation for much of subsequent work in the region (Sellers et al., 1995, 1997). ARCTAS focused on Arctic atmospheric composition and climate (Jacob et al., 2010). As was previously mentioned, CARVE measures large-scale carbon fluxes and surface controls in Alaska (Miller et al., 2010). The Arctic Boreal Vulnerability Experiment aims to investigate the role of interactions between climate, permafrost, hydrology, and disturbance in driving ecosystem processes, focusing on Alaska and northwestern Canada (Goetz et al., 2011). The Next Generation Ecological Experiment addresses how permafrost degradation in a warming Arctic (focusing on Alaska), and the associated changes in landscape evolution, hydrology, soil biogeochemical processes, and plant community succession, will affect feedbacks to the climate system (Wullschleger et al., 2011).

All of these campaigns include the larger Alaskan Arctic and boreal domain as the major region of focus and encompass overlapping scientific questions that directly build on the uncertainty in the processes represented in the global models of our study. For CARVE, ABoVE, and NGEE Arctic, in particular, these campaigns (i.e. all 3) must sample the geographic regions that encompass both the greatest representativeness and the greatest uncertainties. Our uncertainty maps alone provide a guide for campaign sampling location strategy. To reduce uncertainties in NEE, for instance, sampling should be done near the Brooks Range of the North Slope $\left(\sim 69^{\circ} \mathrm{N},-153^{\circ} \mathrm{W}\right)$, along the Northwest Seward Peninsula, and along the lower Yukon; measurements should be within $0.19 \mathrm{~kg} \mathrm{C} \mathrm{m}^{-2} \mathrm{yr}^{-1}$ accuracy and precision. Soil $\mathrm{C}$ in particular should be measured within $9.2 \mathrm{~kg} \mathrm{C} \mathrm{m}^{-2}$ accuracy and precision, along with the environmental and biological factors controlling soil $\mathrm{C}$ processes, to help improve models. The next step to reducing uncertainties is to benchmark the models used in this analysis against the wealth of data that will be generated by CARVE, ABoVE, and NGEE. Models can be rejected that fall outside measurement uncertainty and fail to show improvement against these data. Our results highlight the delicate source/sink balance of the current Alaskan Arctic and boreal terrestrial carbon system and its high sensitivity to future climate change.

\section{Conclusions}

Because of the rapid rate of change in the Arctic as a result of the changing global climate, and because of the actual and potential very large feedbacks from the Arctic to climate change, the Arctic is a critically important region not only for study, but also for accurate representations of current and future feedbacks on global carbon cycle and climate dynamics. We presented here the largest-ever multi-terrestrial biosphere model assessment of carbon dynamics and associated uncertainties for the Alaskan Arctic and boreal region, integrating recent TRENDY, WETCHIMP, and NACP site and regional syntheses model intercomparison projects. Spatial and temporal uncertainties in $\mathrm{CO}_{2}$ fluxes, $\mathrm{CH}_{4}$ fluxes, and soil carbon stocks were understandably large, and we provide a quantified baseline of those uncertainties for future campaigns, model developments, and climate assessments to 
reference and build upon. Further work should focus not only on reducing climate uncertainty impacts on the Arctic and boreal carbon cycle, but also should converge on understanding and estimating the current state of the Arctic and boreal carbon cycle.

\section{The Supplement related to this article is available online at doi:10.5194/bg-11-4271-2014-supplement.}

Author contribution. J. B. F. and C. E. M. formulated idea; J. B. F. designed research; J. B. F. and M. S. performed research; W. C. O. provided data; A. A., A. M. A., I. B., J. M. C., C. D., M. D., B. E.M., D. H., C. H., A. J., P. E. L., M. R. L., B. P., D. P., A. K. S., K. S., J. M., H. T., E. T., H. V., N. V., R. W., and N. Z. provided model output; all authors contributed to the writing of the paper.

Acknowledgements. Part of the research described in this paper was performed for the Carbon in Arctic Reservoirs Vulnerability Experiment (CARVE), an Earth Ventures (EV-1) investigation by the Jet Propulsion Laboratory, California Institute of Technology, under a contract with the National Aeronautics and Space Administration. This work also supports the NASA Arctic-Boreal Vulnerability Experiment (ABoVE) and the NASA Terrestrial Ecology Program. Funding for W. C. O. was provided by the US Department of Energy (Terrestrial Ecosystems Program) and NSF by the Office of Polar Programs and the Division of Environmental Biology. Funding for C.H. was provided by the UK NERC ARCC (Arctic Responses to a Changing Climate) programme. J. R. M. was supported by a NSERC Visiting Postdoctoral Fellowship. R. Grant, F. Hoffman, S. Levis, J. Randerson, D. Ricciuto, G. van der Werf, E. Weng, and S. Zaehle provided model output for ecosys, CLM-CASA, CLM4-CN, CASA-TRANSCOM, LoTEC, CASA-GFED, TECO, and O-CN, respectively. P. Thornton and S. Sitch helped coordinate the NACP site and TRENDY syntheses, respectively. We thank D. McGuire and anonymous reviewers for comments on the manuscript. Copyright 2014 California Institute of Technology. Government sponsorship acknowledged.

Edited by: J.-A. Subke

\section{References}

Agarwal, D. A., Humphrey, M., Beekwilder, N. F., Jackson, K. R., Goode, M. M., and van Ingen, C.: A data-centered collaboration portal to support global carbon-flux analysis, Concurr. Computat., 22, 2323-2334, 2010.

Arain, M. A., Yuan, F., and Andrew Black, T.: Soil-plant nitrogen cycling modulated carbon exchanges in a western temperate conifer forest in Canada, Agr. Forest Meteorol., 140, 171-192, 2006

Baker, I. T., Prihodko, L., Denning, A. S., Goulden, M., Miller, S., and da Rocha, H. R.: Seasonal drought stress in the Amazon: Reconciling models and observations, J. Geophys. Res., 113, G00B01, doi:10.1029/2007jg000644 2008.
Baldocchi, D.: "Breathing" of the terrestrial biosphere: lessons learned from a global network of carbon dioxide flux measurement systems, Austr. J. Botany, 56, 1-26, 2008.

Belshe, E. F., Schuur, E. A. G., Bolker, B. M., and Bracho, R.: Incorporating spatial heterogeneity created by permafrost thaw into a landscape carbon estimate, J. Geophys. Res., 117, G01026, doi:10.1029/2011JG001836, 2012.

Belshe, E. F., Schuur, E. A. G., and Bolker, B. M.: Tundra ecosystems observed to be $\mathrm{CO} 2$ sources due to differential amplification of the carbon cycle, Ecol. Lett., 16, 1307-1315, 2013.

Billings, W. D., Luken, J. O., Mortensen, D. A., and Peterson, K. M.: Arctic tundra: A source or sink for atmospheric carbon dioxide in a changing environment?, Oecologia, 53, 7-11, 1982.

Burke, E. J., Hartley, I. P., and Jones, C. D.: Uncertainties in the global temperature change caused by carbon release from permafrost thawing, The Cryosphere, 6, 1063-1076, doi:10.5194/tc6-1063-2012, 2012.

Cess, R. D., Potter, R. D., Zhang, M.-H., Blanchet, J.-P., Chalita, S., Colman, R., Dazlich, D. A., Genio, A. D. d., Dymnikov, V., Galin, V., Jerrett, D., Keup, E., Lacis, A. A., Le Treut, H., Liang, X.-Z., Mahfouf, J.-F., McAvaney, B. J., Meleshko, V. P., Mitchell, J. F. B., Morcrette, J.-J., Norris, P. M., Randall, D. A., Rikus, L., Roeckner, E., Royer, J.-F., Schlese, U., Sheinin, D. A., Slingo, J. M., Sokolov, A. S., Taylor, K. E., Washington, W. M., Wetherald, R. T., and Yagai, I.: Interpretation of snow-climate feedback as produced by 17 General Circulation Models, Science, 253, 888892, 1991.

Chapin, F. S., Sturm, M., Serreze, M. C., McFadden, J. P., Key, J. R., Lloyd, A. H., McGuire, A. D., Rupp, T. S., Lynch, A. H., Schimel, J. P., Beringer, J., Chapman, W. L., Epstein, H. E., Euskirchen, E. S., Hinzman, L. D., Jia, G., Ping, C.-L., Tape, K. D., Thompson, C. D. C., Walker, D. A., and Welker, J. M.: Role of land-surface changes in Arctic summer warming, Science, 310, 657-660, 2005.

Chapman, W. L. and Walsh, J. E.: Recent variations of sea ice and air temperature in high latitudes, Bull. Am. Meteorol. Soc., 74, 33-47, 1993.

Chapman, W. L. and Walsh, J. E.: Simulations of Arctic temperature and pressure by global coupled models, J. Climate, 20, 609-632, 2007.

Chen, J. M., Liu, J., Cihlar, J., and Goulden, M. L.: Daily canopy photosynthesis model through temporal and spatial scaling for remote sensing applications, Ecol. Modell., 124, 99-119, 1999.

Christensen, T. R., Johansson, T., Åkerman, H. J., Mastepanov, M., Malmer, N., Friborg, T., Crill, P., and Svensson, B H.: Thawing sub-arctic permafrost: Effects on vegetation and methane emissions, Geophys. Res. Lett., 31, L04501, doi:10.1029/2003g1018680, 2004.

Clark, D. B., Mercado, L. M., Sitch, S., Jones, C. D., Gedney, N., Best, M. J., Pryor, M., Rooney, G. G., Essery, R. L. H., Blyth, E., Boucher, O., Harding, R. J., Huntingford, C., and Cox, P. M.: The Joint UK Land Environment Simulator (JULES), model description - Part 2: Carbon fluxes and vegetation dynamics, Geosci Model Dev., 4, 701-722, doi:10.5194/gmd-4-701-2011, 2011.

Cramer, W., Bondeau, A., Woodward, F. I., Prentice, I. C., Betts, R. A., Brovkin, V., Cox, P. M., Fisher, V., Foley, J. A., Friend, A. D., Kucharik, C., Lomas, M. R., Ramankutty, N., Sitch, S., Smith, B., White, A., and Young-Molling, C.: Global response of terrestrial ecosystem structure and function to $\mathrm{CO}_{2}$ and cli- 
mate change: results from six dynamic global vegetation models, Glob. Change Biol., 7, 357-373, 2001.

de Gonçalves, L. G. G., Borak, J. S., Costa, M. H., Saleska, S. R., Baker, I., Restrepo-Coupe, N., Muza, M. N., Poulter, B., Verbeeck, H., Fisher, J. B., Arain, M. A., Arkin, P., Cestaro, B. P., Christoffersen, B., Galbraith, D., Guan, X., van den Hurk, B. J. J. M., Ichii, K., Imbuzeiro, H. M. A., Jain, A. K., Levine, N., Lu, C., Miguez-Macho, G., Roberti, D. R., Sahoo, A., Sakaguchi, K., Schaefer, K., Shi, M., Shuttleworth, W. J., Tian, H., Yang, Z.-L., and Zeng, X.: Overview of the Large-Scale BiosphereAtmosphere Experiment in Amazonia Data Model Intercomparison Project (LBA-DMIP), Agr. Forest Meteorol., 182/183, 111127, 2013.

El Maayar, M., Price, D. T., Black, T. A., Humphreys, E. R., and Jork, E. M.: Sensitivity tests of the integrated biosphere simulator to soil and vegetation characteristics in a pacific coastal coniferous forest, Atmos.-Oc., 40, 313-332, 2002.

Friedlingstein, P., Cox, P., Betts, R., Bopp, L., von Bloh, W., Brovkin, V., Cadule, P., Doney, S., Eby, M., Fung, I., Bala, G., John, J., Jones, C., Joos, F., Kato, T., Kawamiya, M., Knorr, W., Lindsay, K., Matthews, H. D., Raddatz, T., Rayner, P., Reick, C., Roeckner, E., Schnitzler, K. G., Schnur, R., Strassmann, K., Weaver, A. J., Yoshikawa, C., and Zeng, N.: Climate-carbon cycle feedback analysis: Results from the C4MIP model intercomparison, J. Climate, 19, 3337-3353, 2006.

Goetz, S., Kimball, J., Mack, M., and Kasischke, E.: Scoping Completed for an Experiment to Assess Vulnerability of Arctic and Boreal Ecosystems, Eos Trans. AGU, 92, p. 1, 2011.

Grant, R. F., Barr, A. G., Black, T. A., Margolis, H. A., Dunn, A. L., Metsaranta, J., Wang, S., McCaughey, J. H., and Bourque, C. A.: Interannual variation in net ecosystem productivity of Canadian forests as affected by regional weather patterns - A FluxnetCanada synthesis, Agr. Forest Meteorol., 149, 2022-2039, 2009.

Harriss, R. C., Wofsy, S. C., Hoell, J. M., Jr., Bendura, R. J., Drewry, J. W., McNeal, R. J., Pierce, D., Rabine, V., and Snell, R. L.: The Arctic Boundary Layer Expedition (ABLE-3B), J. Geophys. Res., 99, 1635-1643, 1994.

Hayes, D. J., McGuire, A. D., Kicklighter, D. W., Gurney, K. R., Burnside, T. J., and Melillo, J. M.: Is the northern high-latitude land-based $\mathrm{CO}_{2}$ sink weakening?, Global Biogeochem. Cy., 25, GB3018, doi:10.1029/2010GB003813, 2011.

Hayes, D. J., Turner, D. P., Stinson, G., McGuire, A. D., Wei, Y., West, T. O., Heath, L. S., de Jong, B., McConkey, B. G., Birdsey, R. A., Kurz, W. A., Jacobson, A. R., Huntzinger, D. N., Pan, Y., Post, W. M., and Cook, R. B.: Reconciling estimates of the contemporary North American carbon balance among terrestrial biosphere models, atmospheric inversions, and a new approach for estimating net ecosystem exchange from inventory-based data, Glob. Change Biol., 18, 1282-1299, 2012.

Hinzman, L., Bettez, N., Bolton, W., Chapin, F., Dyurgerov, M., Fastie, C., Griffith, B., Hollister, R., Hope, A., Huntington, H., Jensen, A., Jia, G., Jorgenson, T., Kane, D., Klein, D., Kofinas, G., Lynch, A., Lloyd, A., McGuire, A., Nelson, F., Oechel, W., Osterkamp, T., Racine, C., Romanovsky, V., Stone, R., Stow, D., Sturm, M., Tweedie, C., Vourlitis, G., Walker, M., Walker, D., Webber, P., Welker, J., Winker, K., and Yoshikawa, K.: Evidence and implications of recent climate change in northern Alaska and other Arctic regions, Clim. Change, 72, 251-298, 2005.
Hugelius, G., Tarnocai, C., Broll, G., Canadell, J. G., Kuhry, P., and Swanson, D. K.: The Northern Circumpolar Soil Carbon Database: spatially distributed datasets of soil coverage and soil carbon storage in the northern permafrost regions, Earth Syst. Sci. Data, 5, 3-13, doi:10.5194/essd-5-3-2013, 2013.

Huntzinger, D. N., Post, W. M., Wei, Y., Michalak, A. M., West, T. O., Jacobson, A. R., Baker, I. T., Chen, J. M., Davis, K. J., Hayes, D. J., Hoffman, F. M., Jain, A. K., Liu, S., McGuire, A. D., Neilson, R. P., Potter, C., Poulter, B., Price, D., Raczka, B. M., Tian, H. Q., Thornton, P., Tomelleri, E., Viovy, N., Xiao, J., Yuan, W., Zeng, N., Zhao, M., and Cook, R.: North American Carbon Program (NACP) regional interim synthesis: terrestrial biospheric model intercomparison, Ecol. Modell., 232, 144-157, 2012.

IPCC: Contribution of Working Group I to the Fourth Assessment Report of the Intergovernmental Panel on Climate Change, in: Climate Change 2007: The Physical Science Basis, edited by: Solomon, S., Qin, D., Manning, M., Chen, Z., Marquis, M., Averyt, K. B., Tignor, M., and Miller, H. L., Cambridge University Press, Cambridge, United Kingdrom and New York, NY, USA, 2007.

Jacob, D. J., Crawford, J. H., Maring, H., Clarke, A. D., Dibb, J. E., Emmons, L. K., Ferrare, R. A., Hostetler, C. A., Russell, P. B., Singh, H. B., Thompson, A. M., Shaw, G. E., McCauley, E., Pederson, J. R., and Fisher, J. A.: The Arctic Research of the Composition of the Troposphere from Aircraft and Satellites (ARCTAS) mission: design, execution, and first results, Atmos. Chem. Phys., 10, 5191-5212, doi:10.5194/acp-10-5191-2010, 2010.

Jain, A. K. and Yang, X.: Modeling the effects of two different land cover change data sets on the carbon stocks of plants and soils in concert with $\mathrm{CO}_{2}$ and climate change, Global Biogeochem. Cy., 19, GB2015, doi:10.1029/2004gb002349, 2005.

Johnson, K. D., Harden, J., McGuire, A. D., Bliss, N. B., Bockheim, J. G., Clark, M., Nettleton-Hollingsworth, T., Jorgenson, M. T., Kane, E. S., Mack, M., O’Donnell, J., Ping, C.-L., Schuur, E. A. G., Turetsky, M. R., and Valentine, D. W.: Soil carbon distribution in Alaska in relation to soil-forming factors, Geoderma, 167/168, 71-84, 2011.

Koven, C. D., Ringeval, B., Friedlingstein, P., Ciais, P., Cadule, P., Khvorostyanov, D., Krinner, G., and Tarnocai, C.: Permafrost carbon-climate feedbacks accelerate global warming, Proc. Natl. Acad. Sci., 108, 14769-14774, 2011.

Krinner, G., Viovy, N., de Noblet-Ducoudré, N., Ogée, J., Polcher, J., Friedlingstein, P., Ciais, P., Sitch, S., and Prentice, C. I.: Evaluation of ecosystem dynamics, plant geography and terrestrial carbon cycling in the LPJ dynamic global vegetation model, Global Biogeochem. Cy., 19, 1-33, 2005.

Kuhry, P., Ping, C.-L., Schuur, E. A. G., Tarnocai, C., and Zimov, S.: Report from the International Permafrost Association: carbon pools in permafrost regions, Permafr. Perigl. Proc., 20, 229-234, 2009.

Kwon, H.-J., Oechel, W. C., Zulueta, R. C., and Hastings, S. J.: Effects of climate variability on carbon sequestration among adjacent wet sedge tundra and moist tussock tundra ecosystems, J. Geophys. Res., 111, G03014, doi:10.1029/2005jg000036, 2006.

Levy, P. E., Cannell, M. G. R., and Friend, A. D.: Modelling the impact of future changes in climate, $\mathrm{CO}_{2}$ concentration and land use on natural ecosystems and the terrestrial carbon sink, Glob. Environ. Change, 14, 21-30, 2004. 
Mack, M. C., Schuur, E. A. G., Bret-Harte, M. S., Shaver, G. R., and Chapin, F. S.: Ecosystem carbon storage in arctic tundra reduced by long-term nutrient fertilization, Nature, 431, 440-443, 2004.

Marion, G. M. and Oechel, W. C.: Mid- to late-Holocene carbon balance in Arctic Alaska and its implications for future global warming, The Holocene, 3, 193-200, 1993.

McGuire, A. D., Chapin, F. S., Walsh, J. E., and Wirth, C.: Integrated regional changes in Arctic climate feedbacks: implications for the global climate system, Ann. Rev. Environ. Resour., 31, 61-91, 2006.

McGuire, A. D., Anderson, L. G., Christensen, T. R., Dallimore, S., Guo, L., Hayes, D. J., Heimann, M., Lorenson, T. D., Macdonald, R. W., and Roulet, N.: Sensitivity of the carbon cycle in the Arctic to climate change, Ecol. Monogr., 79, 523-555, 2009.

McGuire, A. D., Christensen, T. R., Hayes, D., Heroult, A., Euskirchen, E., Kimball, J. S., Koven, C., Lafleur, P., Miller, P. A., Oechel, W., Peylin, P., Williams, M., and Yi, Y.: An assessment of the carbon balance of Arctic tundra: comparisons among observations, process models, and atmospheric inversions, Biogeosciences, 9, 3185-3204, doi:10.5194/bg-9-3185-2012, 2012.

Melton, J. R., Wania, R., Hodson, E. L., Poulter, B., Ringeval, B., Spahni, R., Bohn, T., Avis, C. A., Beerling, D. J., Chen, G., Eliseev, A. V., Denisov, S. N., Hopcroft, P. O., Lettenmaier, D. P., Riley, W. J., Singarayer, J. S., Subin, Z. M., Tian, H., Zürcher, S., Brovkin, V., van Bodegom, P. M., Kleinen, T., Yu, Z. C., and Kaplan, J. O.: Present state of global wetland extent and wetland methane modelling: conclusions from a model intercomparison project (WETCHIMP), Biogeosciences, 10, 753788, doi:10.5194/bg-10-753-2013, 2013.

Miller, C. E., Dinardo, S. J., and Carve Science Team: CARVE: The Carbon in Arctic Reservoirs Vulnerability Experiment, American Geophysical Union, Fall Meeting 2010, San Francisco, 2010.

Mishra, U. and Riley, W. J.: Alaskan soil carbon stocks: spatial variability and dependence on environmental factors, Biogeosciences, 9, 3637-3645, doi:10.5194/bg-9-3637-2012, 2012.

Mueller, B., Seneviratne, S. I., Jiménez, C., Corti, T., Hirschi, M., Balsamo, G., Ciais, P., Dirmeyer, P. A., Fisher, J. B., Guo, Z., Jung, M., Maignan, F., McCabe, M. F., Reichle, R. H., Reichstein, M., Rodell, M., Sheffield, J., Teuling, A. J., Wang, K., Wood, E. F., and Zhang, Y.: Evaluation of global observationsbased evapotranspiration datasets and IPCC AR4 simulations, Geophys. Res. Lett., 38, L06402, doi:10.1029/2010GL046230, 2011.

Mueller, K. L., Yadav, V., Curtis, P. S., Vogel, C., and Michalak, A. $\mathrm{M}$.: Attributing the variability of eddy-covariance $\mathrm{CO}_{2}$ flux measurements across temporal scales using geostatistical regression for a mixed northern hardwood forest, Global Biogeochem. Cy., 24, GB3023, 10.1029/2009gb003642, 2010.

Natali, S. M., Schuur, E. A. G., and Rubin, R. L.: Increased plant productivity in Alaskan tundra as a result of experimental warming of soil and permafrost, J. Ecol., 100, 488-498, 2012.

Natali, S. M., E. A. Schuur, E. E. Webb, C. E. H. Pries, and K. G.: Crummer (2014), Permafrost degradation stimulates carbon loss from experimentally warmed tundra, Ecology, 95, 602-608, 2014.

Oechel, W. C. and Vourlitis, G. L.: The effects of climate change land-atmosphere feedbacks in arctic tundra regions, Trends Ecol. Evol., 9, 324-329, 1994.
Oechel, W. C., Hastings, S. J., Vourlrtis, G., Jenkins, M., Riechers, G., and Grulke, N.: Recent change of Arctic tundra ecosystems from a net carbon dioxide sink to a source, Nature, 361, 520-523, 1993.

Oechel, W. C., Vourlitis, G., and Hastings, S. J.: Cold season $\mathrm{CO}_{2}$ emission from Arctic soils, Global Biogeochem. Cy., 11, 163172, 1997.

Oechel, W. C., Vourlitis, G. L., Hastings, S. J., Zulueta, R. C., Hinzman, L., and Kane, D.: Acclimation of ecosystem $\mathrm{CO}_{2}$ exchange in the Alaskan Arctic in response to decadal climate warming, Nature, 406, 978-981, 2000.

Oechel, W. C., Laskowski, C. A., Burba, G., Gioli, B., and Kalhori, A. A.: Annual patterns and budget of $\mathrm{CO}_{2}$ flux in an Arctic tussock tundra ecosystem, J. Geophys. Res., 119, 323-339, 2014.

Olefeldt, D., Turetsky, M. R., Crill, P. M., and McGuire, A. D.: Environmental and physical controls on northern terrestrial methane emissions across permafrost zones, Glob. Change Biol., 19, 589-603, 2013.

Overpeck, J., Hughen, K., Hardy, D., Bradley, R., Case, R., Douglas, M., Finney, B., Gajewski, K., Jacoby, G., Jennings, A., Lamoureux, S., Lasca, A., MacDonald, G., Moore, J., Retelle, M., Smith, S., Wolfe, A., and Zielinski, G.: Arctic environmental change of the last four centuries, Science, 278, 1251-1256, 1997.

Piao, S., Sitch, S., Ciais, P., Friedlingstein, P., Peylin, P., Wang, X., Ahlström, A., Anav, A., Canadell, J. G., Cong, N., Huntingford, C., Jung, M., Levis, S., Levy, P. E., Li, J., Lin, X., Lomas, M. R., Lu, M., Luo, Y., Ma, Y., Myneni, R. B., Poulter, B., Sun, Z., Wang, T., Viovy, N., Zaehle, S., and Zeng, N.: Evaluation of terrestrial carbon cycle models for their response to climate variability and to $\mathrm{CO}_{2}$ trends, Glob. Change Biol., 19, 2117-2132, 2013.

Ping, C.-L., Michaelson, G. J., Jorgenson, M. T., Kimble, J. M., Epstein, H., Romanovsky, V. E., and Walker, D. A.: High stocks of soil organic carbon in the North American Arctic region, Nat. Geosci., 1, 615-619, 2008.

Poulter, B., Frank, D. C., Hodson, E. L., and Zimmermann, N. E.: Impacts of land cover and climate data selection on understanding terrestrial carbon dynamics and the $\mathrm{CO}_{2}$ airborne fraction, Biogeosciences, 8, 2027-2036, doi:10.5194/bg-8-20272011, 2011.

Qian, H., Joseph, R., and Zeng, N.: Enhanced terrestrial carbon uptake in the Northern High Latitudes in the 21st century from the Coupled Carbon Cycle Climate Model Intercomparison Project model projections, Glob. Change Biol., 16, 641-656, 2010.

Randerson, J. T., Thompson, M. V., Conway, T. J., Fung, I. Y., and Field, C. B.: The contribution of terrestrial sources and sinks to trends in the seasonal cycle of atmospheric carbon dioxide, Global Biogeochem. Cy., 11, 535-560, 1997.

Randerson, J. T., Hoffman, F. M., Thornton, P. E., Mahowald, N. M., Lindsay, K., Lee, Y.-H., Nevison, C. D., Doney, S. C., Bonan, G., Stöckli, R., Covey, C., Running, S. W., and Fung, I. Y.: Systematic assessment of terrestrial biogeochemistry in coupled climate-carbon models, Glob. Change Biol., 15, 2462-2484, 2009.

Rienecker, M. M., Suarez, M. J., Gelaro, R., Todling, R., Bacmeister, J., Liu, E., Bosilovich, M. G., Schubert, S. D., Takacs, L., Kim, G.-K., Bloom, S., Chen, J., Collins, D., Conaty, A., da Silva, A., Gu, W., Joiner, J., Koster, R. D., Lucchesi, R., Molod, A., Owens, T., Pawson, S., Pegion, P., Redder, C. R., Reichle, R., 
Robertson, F. R., Ruddick, A. G., Sienkiewicz, M., and Woollen, J.: MERRA: NASA's Modern-Era Retrospective Analysis for Research and Applications, J. Climate, 24, 3624-3648, 2011.

Riley, W. J., Subin, Z. M., Lawrence, D. M., Swenson, S. C., Torn, M. S., Meng, L., Mahowald, N. M., and Hess, P.: Barriers to predicting changes in global terrestrial methane fluxes: analyses using CLM4Me, a methane biogeochemistry model integrated in CESM, Biogeosciences, 8, 1925-1953, doi:10.5194/bg-8-19252011, 2011.

Schaefer, K., Collatz, G. J., Tans, P., Denning, A. S., Baker, I., Berry, J., Prihodko, L., Suits, N., and Philpott, A.: Combined Simple Biosphere/Carnegie-Ames-Stanford Approach terrestrial carbon cycle model, J. Geophys. Res., 113, G03034, doi:10.1029/2007jg000603, 2008.

Schaefer, K., Zhang, T., Bruhwiler, L., and Barrett, A. P.: Amount and timing of permafrost carbon release in response to climate warming, Tellus B, 63, 165-180, 2011.

Schaefer, K. M., Schwalm, C. R., Williams, C. A., Arain, M., Barr, A. G., Chen, J. M., Davis, K. J., Dimitrov, D. D., Hilton, T. W., Hollinger, D. Y., Humphreys, E., Poulter, B., Raczka, B., Richardson, A. D., Sahoo, A., Thornton, P. E., Vargas, R., Verbeeck, H., Anderson, R. S., Baker, I., Black, T., Bolstad, P. V., Chen, J., Curtis, P., Desai, A. R., Dietze, M., Dragoni, D., Gough, C., Grant, R. F., Gu, L., Jain, A., Kucharik, C. J., Law, B. E., Liu, S., Lokipitiya, E., Margolis, H., Matamala, R., McCaughey, J., Monson, R. K., Munger, J., Oechel, W. C., Peng, C., Price, D. T., Ricciuto, D. M., Riley, W. J., Roulet, N. T., Tian, H., Tonitto, C., Torn, M. S., Weng, E., and Zhou, X.: A model-data comparison of Gross Primary Productivity: Results from the North American Carbon Program site synthesis, J. Geophys. Res., 117, G03010, doi:10.1029/2012JG001960, 2012.

Schuur, E. A. G. and Abbott, B.: Climate change: high risk of permafrost thaw, Nature, 480, 32-33, 2011.

Schuur, E. A. G., Bockheim, J., Canadell, J. G., Euskirchen, E., Field, C. B., Goryachkin, S. V., Hagemann, S., Kuhry, P., Lafleur, P. M., Lee, H., Mazhitova, G., Nelson, F. E., Rinke, A., Romanovsky, V. E., Shiklomanov, N., Tarnocai, C., Venevsky, S., Vogel, J. G., and Zimov, S. A.: Vulnerability of permafrost carbon to climate change: implications for the global carbon cycle, BioScience, 58, 701-714, 2008.

Schuur, E. A. G., Vogel, J. G., Crummer, K. G., Lee, H., Sickman, J. O., and Osterkamp, T. E.: The effect of permafrost thaw on old carbon release and net carbon exchange from tundra, Nature, 459, 556-559, 2009.

Schuur, E. A. G., Abbott, B. W., Bowden, W. B., Brovkin, V., Camill, P., Canadell, J. G., Chanton, J. P., Chapin, F. S., III, Christensen, T. R., Ciais, P., Crosby, B. T., Czimczik, C. I., Grosse, G., Harden, J., Hayes, D. J., Hugelius, G., Jastrow, J. D., Jones, J. B., Kleinen, T., Koven, C. D., Krinner, G., Kuhry, P., Lawrence, D. M., McGuire, A. D., Natali, S. M., O’Donnell, J. A., Ping, C. L., Riley, W. J., Rinke, A., Romanovsky, V. E., Sannel, A. B. K., Schädel, C., Schaefer, K., Sky, J., Subin, Z. M., Tarnocai, C., Turetsky, M. R., Waldrop, M. P., Walter Anthony, K. M., Wickland, K. P., Wilson, C. J., and Zimov, S. A.: Expert assessment of vulnerability of permafrost carbon to climate change, Clim. Change, 119, 359-374, 2013.

Schwalm, C. R., Williams, C. A., Schaefer, K., Anderson, R., Arain, M. A., Baker, I., Barr, A., Black, T. A., Chen, G., Chen, J. M., Ciais, P., Davis, K. J., Desai, A., Dietze, M., Dragoni, D., Fis- cher, M. L., Flanagan, L. B., Grant, R., Gu, L., Hollinger, D., Izaurralde, R. C., Kucharik, C., Lafleur, P., Law, B. E., Li, L., Li, Z., Liu, S., Lokupitiya, E., Luo, Y., Ma, S., Margolis, H., Matamala, R., McCaughey, H., Monson, R. K., Oechel, W. C., Peng, C., Poulter, B., Price, D. T., Riciutto, D. M., Riley, W., Sahoo, A. K., Sprintsin, M., Sun, J., Tian, H., Tonitto, C., Verbeeck, H., and Verma, S. B.: A model-data intercomparison of $\mathrm{CO}_{2}$ exchange across North America: Results from the North American Carbon Program site synthesis, J. Geophys. Res., 115, G00H05, doi:10.1029/2009jg001229, 2010.

Sellers, P., Berry, J., Collatz, G., Field, C., and Hall, F.: Canopy reflectance, photosynthesis, and transpiration. III. A reanalysis using improved leaf models and a new canopy integration scheme, Remote Sens. Environ., 42, 187-216, 1992.

Sellers, P., Hall, F., Margolis, H., Kelly, B., Baldocchi, D., den Hartog, G., Cihlar, J., Ryan, M. G., Goodison, B., Crill, P., Ranson, K. J., Lettenmaier, D., and Wickland, D. E.: The boreal ecosystem-atmosphere study (BOREAS): an overview and early results from the 1994 field year, Bull. Amer. Meteorol. Soc., 76, 1549-1577, 1995.

Sellers, P. J., Hall, F. G., Kelly, R. D., Black, A., Baldocchi, D., Berry, J., Ryan, M., Ranson, K. J., Crill, P. M., Lettenmaier, D. P., Margolis, H., Cihlar, J., Newcomer, J., Fitzjarrald, D., Jarvis, P. G., Gower, S. T., Halliwell, D., Williams, D., Goodison, B., Wickland, D. E., and Guertin, F. E.: BOREAS in 1997: Experiment overview, scientific results, and future directions, J. Geophys. Res., 102, 28731-28769, 1997.

Serreze, M. C., Walsh, J. E., Chapin, F. S., Osterkamp, T., Dyurgerov, M., Romanovsky, V., Oechel, W. C., Morison, J., Zhang, T., and Barry, R. G.: Observational evidence of recent change in the northern high-latitude environment, Clim. Change, 46, 159-207, 2000.

Sistla, S. A., Moore, J. C., Simpson, R. T., Gough, L., Shaver, G. R., and Schimel, J. P.: Long-term warming restructures Arctic tundra without changing net soil carbon storage, Nature, advance online publication, 2013.

Sitch, S., Smith, B., Prentice, C. I., Arneth, A., Bondeau, A., Cramer, W., Kaplan, J. O., Lucht, W., Sykes, M. T., Thonicke, K., and Venevsky, S.: Evaluation of ecosystem dynamics, plant geography and terrestrial carbon cycling in the LPJ dynamic global vegetation model, Glob. Change Biol., 9, 161-185, 2003.

Smith, B., Prentice, I. C., and Sykes, M. T.: Representation of vegetation dynamics in modelling of terrestrial ecosystems: comparing two contrasting approaches within European climate space, Glob. Ecol. Biogeogr., 10, 621-637, 2001.

Spahni, R., Wania, R., Neef, L., van Weele, M., Pison, I., Bousquet, P., Frankenberg, C., Foster, P. N., Joos, F., Prentice, I. C., and van Velthoven, P.: Constraining global methane emissions and uptake by ecosystems, Biogeosciences, 8, 1643-1665, doi:10.5194/bg8-1643-2011, 2011.

Tarnocai, C.: The effect of climate change on carbon in Canadian peatlands, Glob. Planet. Change, 53, 222-232, 2006.

Tarnocai, C., Canadell, J. G., Schuur, E. A. G., Kuhry, P., Mazhitova, G., and Zimov, S.: Soil organic carbon pools in the northern circumpolar permafrost region, Global Biogeochem. Cy., 23, GB2023, doi:10.1029/2008GB003327, 2009.

Thornton, P. E., Lamarque, J.-F., Rosenbloom, N. A., and Mahowald, N. M.: Influence of carbon-nitrogen cycle coupling on 
land model response to $\mathrm{CO}_{2}$ fertilization and climate variability, Global Biogeochem. Cy., 21, 1-15, 2007.

Tian, H., Chen, G., Liu, M., Zhang, C., Sun, G., Lu, C., Xu, X., Ren, W., Pan, S., and Chappelka, A.: Model estimates of net primary productivity, evapotranspiration, and water use efficiency in the terrestrial ecosystems of the southern United States during 18952007, Forest Ecol. Manage., 259, 1311-1327, 2010.

Tian, H., Chen, G., Lu, C., Xu, X., Hayes, D. J., Ren, W., Pan, S., Huntzinger, D. N., and Wofsy, S. C.: North American terrestrial $\mathrm{CO}_{2}$ uptake largely offset by $\mathrm{CH} 4$ and $\mathrm{N}_{2} \mathrm{O}$ emissions: toward a full accounting of the greenhouse gas budget, Clim. Change, in press, 1-14, 2014.

van der Werf, G. R., Randerson, J. T., Collatz, G. J., Giglio, L., Kasibhatla, P. S., Arellano, A. F., Olsen, S. C., and Kasischke, E. S.: Continental-scale partitioning of fire emissions during the 1997-2001 El Niño/La Niña period, Science, 303, 73-76, 2004.

Walsh, J. E., Kattsov, V. M., Chapman, W. L., Govorkova, V., and Pavlova, T.: Comparison of Arctic climate simulations by uncoupled and coupled global models, J. Climate, 15, 1429-1446, 2002.

Wang, T., Ciais, P., Piao, S. L., Ottlé, C., Brender, P., Maignan, F., Arain, A., Cescatti, A., Gianelle, D., Gough, C., Gu, L., Lafleur, P., Laurila, T., Marcolla, B., Margolis, H., Montagnani, L., Moors, E., Saigusa, N., Vesala, T., Wohlfahrt, G., Koven, C., Black, A., Dellwik, E., Don, A., Hollinger, D., Knohl, A., Monson, R., Munger, J., Suyker, A., Varlagin, A., and Verma, S.: Controls on winter ecosystem respiration in temperate and boreal ecosystems, Biogeosciences, 8, 2009-2025, doi:10.5194/bg8-2009-2011, 2011.

Wania, R., Ross, I., and Prentice, I. C.: Implementation and evaluation of a new methane model within a dynamic global vegetation model: LPJ-WHyMe v1.3.1, Geosci. Model Dev., 3, 565-584, doi:10.5194/gmd-3-565-2010, 2010.

Wania, R., Melton, J. R., Hodson, E. L., Poulter, B., Ringeval, B., Spahni, R., Bohn, T., Avis, C. A., Chen, G., Eliseev, A. V., Hopcroft, P. O., Riley, W. J., Subin, Z. M., Tian, H., van Bodegom, P. M., Kleinen, T., Yu, Z. C., Singarayer, J. S., Zürcher, S., Lettenmaier, D. P., Beerling, D. J., Denisov, S. N., Prigent, C., Papa, F., and Kaplan, J. O.: Present state of global wetland extent and wetland methane modelling: methodology of a model inter-comparison project (WETCHIMP), Geosci. Model Dev., 6, 617-641, doi:10.5194/gmd-6-617-2013, 2013.
Weng, E. and Luo, Y.: Soil hydrological properties regulate grassland ecosystem responses to multifactor global change: A modeling analysis, J. Geophys. Res., 113, G03003, doi:10.1029/2007jg000539, 2008.

Wullschleger, S. D., Hinzman, L. D., and Wilson, C. J.: Planning the Next Generation of Arctic Ecosystem Experiments, Eos Trans. AGU, 92, p. 145, 2011.

Xue, Y., Sellers, P. J., Kinter, J. L., and Shukla, J.: A simplified biosphere model for global climate studies, J. Climate, 4, 345364, 1991.

Yadav, V., Mueller, K. L., Dragoni, D., and Michalak, A. M.: A geostatistical synthesis study of factors affecting gross primary productivity in various ecosystems of North America, Biogeosciences, 7, 2655-2671, doi:10.5194/bg-7-2655-2010, 2010.

Zaehle, S., Friend, A. D., Friedlingstein, P., Dentener, F., Peylin, P., and Schulz, M.: Carbon and nitrogen cycle dynamics in the O-CN land surface model, II: The role of the nitrogen cycle in the historical terrestrial C balance, Global Biogeochem. Cy., 24, 1-14, 2010.

Zeng, N., Qian, H., Roedenbeck, C., and Heimann, M.: Impact of 1998-2002 midlatitude drought and warming on terrestrial ecosystem and the global carbon cycle, Geophys. Res. Lett., 32, L22709, doi:10.1029/2005g1024607, 2005.

Zhao, M. S., Heinsch, F. A., Nemani, R. R., and Running, S. W.: Improvements of the MODIS terrestrial gross and net primary production global data set, Remote Sens. Environ., 98, 164-176, 2005.

Zimov, S. A., Schuur, E. A. G., and Chapin, F. S.: Permafrost and the global carbon budget, Science, 312, 1612-1613, 2006.

Zona, D., Oechel, W., Peterson, K., Clements, R., PAW U, K., and Ustin, S.: Characterization of the carbon fluxes of a vegetated drained lake basin chronosequence on the Alaskan Arctic Coastal Plain, Glob. Change Biol., 16, 1870-1882, 2010. 